\title{
Effects of feeding synthetic zeolite A during the prepartum period on serum mineral concentration, oxidant status, and performance of multiparous Holstein cows
}

\author{
A. L. Kerwin, ${ }^{1}$ C. M. Ryan, ${ }^{1}$ B. M. Leno, ${ }^{1}$ M. Jakobsen, ${ }^{2}$ P. Theilgaard, ${ }^{3}$ D. M. Barbano, ${ }^{4}$ and T. R. Overton ${ }^{1 *}$ \\ ${ }^{1}$ Department of Animal Science, Cornell University, Ithaca, NY 14853 \\ ${ }^{2}$ Protekta Inc., Lucknow, ON, Canada NOG $2 \mathrm{HO}$ \\ ${ }^{3}$ Vilofoss, Graasten, Denmark 6300 \\ ${ }^{4}$ Department of Food Science, Cornell University, Ithaca, NY 14853
}

\section{ABSTRACT}

The objective of this study was to determine the effects of feeding synthetic zeolite A for 3 wk before expected calving on peripartal serum mineral concentrations, hypocalcemia, oxidant status, and performance. Holstein cows $(\mathrm{n}=55)$ entering their second or greater lactations were assigned randomly to 1 of 2 dietary treatments starting $21 \mathrm{~d}$ before expected calving: control (CON: $40 \%$ corn silage, $33 \%$ wheat straw, and $27 \%$ concentrate; $n=29$ ) or experimental [EXP: CON plus zeolite A (X-Zelit, Protekta Inc., Lucknow, ON, Canada/Vilofoss, Graasten, Denmark; $\mathrm{n}=26$ ) at an inclusion rate of $3.3 \%$ of dry matter, targeting 500 $\mathrm{g} / \mathrm{d}$ as-fed]. Cows were fed the same postpartum diet and housed in individual tiestalls through $28 \mathrm{~d}$ in milk. Cows fed EXP had higher serum Ca concentrations as parturition approached and during the immediate postpartum period. Serum P concentrations were lower for the EXP-fed cows during the prepartum period and the first $2 \mathrm{~d}$ of lactation, whereas serum $\mathrm{Mg}$ concentrations were lower than those of the CON-fed cows only during the immediate periparturient period. Cows fed EXP had decreased prevalence of subclinical hypocalcemia $(\mathrm{SCH})$ from $\mathrm{d}-1$ through 3 relative to day of parturition, with the largest difference occurring within the first day postpartum. Prepartum dry matter intake tended to be decreased and rumination was decreased in cows fed EXP; however; postpartum dry matter intake, rumination, milk yield, milk component yield, and colostrum measurements did not differ between treatments. Cows fed EXP tended to have increased hazard of pregnancy by $150 \mathrm{~d}$ in milk when controlling for parity compared with CON-fed cows; potential reproductive benefits merit further study. This study

Received January 9, 2019

Accepted February 24, 2019.

*Corresponding author: tro2@cornell.edu demonstrated that zeolite A supplementation during the prepartum period results in markedly improved serum Ca concentrations around parturition and similar postpartum performance compared with controls and is effective at decreasing hypocalcemia in multiparous Holstein cows.

Key words: synthetic zeolite A, hypocalcemia, transition cow, mineral metabolism

\section{INTRODUCTION}

A cow's demand for calcium increases as gestation progresses due to the growing fetus; however, the demand increases at least 2-fold around the time of parturition because of colostrogenesis and subsequent milk production (House and Bell, 1993; Goff and Horst, 1997). In combination with decreased peripartal DMI, this puts cows at risk for hypocalcemia (Goff and Horst, 1997). Research has shown that hypocalcemia increases the risk for other health disorders (Kimura et al., 2006; Chapinal et al., 2011; Martinez et al., 2012) and is associated with decreased milk production (Chapinal et al., 2012) and poorer subsequent reproductive performance (Chapinal et al., 2012; Martinez et al., 2012; Caixeta et al., 2017).

Different nutritional strategies have been developed to prevent hypocalcemia. One strategy for preventing hypocalcemia is to feed a Ca-deficient $(<20 \mathrm{~g} / \mathrm{d}$ of absorbable $\mathrm{Ca}$ ) diet during the prepartum period, which will cause a slight decrease in blood $\mathrm{Ca}$ and stimulate parathyroid hormone (PTH) secretion (Goings et al., 1974; Kichura et al., 1982; Goff, 2006). Parathyroid hormone mobilizes skeletal Ca when blood Ca concentrations decrease and stimulates the conversion of the hormone 1,25-dihydroxyvitamin D from vitamin D (Goff, 2006). This hormone increases the absorption efficiency of $\mathrm{Ca}$ in the small intestine and $\mathrm{Ca}$ reabsorption in the kidney (Goff, 2006). Formulating prepartum diets sufficiently low in Ca to induce these physiological changes 
is difficult because of generally higher concentrations of $\mathrm{Ca}$ in common feedstuffs; therefore, prepartum dietary strategies to improve Ca metabolism during the periparturient period have focused on manipulation of the prepartum DCAD (Horst et al., 2005).

One approach to actualize a low-absorbable-Ca diet would be to add a compound to the prepartum diet that would bind dietary Ca and thereby decrease absorption. Synthetic zeolite A is composed of sodium aluminum silicate that can be added to the diet to bind Ca. Thilsing et al. (2006) demonstrated that synthetic zeolite $\mathrm{A}$ had the capacity to bind to $\mathrm{Ca}, \mathrm{P}$, and $\mathrm{Mg}$ in rumen fluid at varying $\mathrm{pH}$ levels in an in vitro system, which was supported by subsequent in vivo work that reported numerical decreases in $\mathrm{Ca}, \mathrm{P}$, and $\mathrm{Mg}$ concentrations in rumen fluid (Grabherr et al., 2009b).

One of the first studies evaluating prepartum dietary zeolite A demonstrated that feeding zeolite A for 4 wk before expected calving improved Ca status on $\mathrm{d}$ 1 postpartum; however, there was a limited number of cows in that study as only 9 Jersey cows were fed zeolite A (Thilsing-Hansen and Jørgensen, 2001). Subsequent studies limited zeolite A supplementation to 2 wk before expected calving (Thilsing et al., 2007; Pallesen et al., 2008; Grabherr et al., 2009a) but also indicated that feeding zeolite A prepartum increased circulating concentrations of total Ca postpartum. Commercial dairy farms in North America typically group dry cows into 1 or 2 groups; a single-group dry cow pen or a far-off dry cow pen with animals typically moving to a closeup pen 21 to $28 \mathrm{~d}$ before expected day of parturition; therefore, it is of interest to evaluate feeding synthetic zeolite A in such a system.

The objective of this study was to determine the effects of supplementing zeolite A for $21 \mathrm{~d}$ before expected day of parturition to multiparous Holstein cows on serum mineral status, plasma oxidant status, DMI, rumination, colostrum, milk yield and composition, health outcomes, and time to pregnancy within 150 DIM. We hypothesized that supplementation of synthetic zeolite A would increase serum Ca concentrations, decrease hypocalcemia, and potentially improve aspects of postpartum performance.

\section{MATERIALS AND METHODS}

\section{Study Population, Experimental Design, and Treatments}

All animal protocols were approved by the Cornell University Institutional Animal Care and Use Committee. Cows entering second or greater lactation at the Cornell University Ruminant Center Dairy Research Farm were enrolled between March and May 2017 in a completely randomized design, with randomization restricted to balance for parity group (entering second vs. third and greater lactation) and previous 305-d mature-equivalent milk production. Sixty cows were enrolled in the study, of which 55 remained in the final data set as described below. Animals were housed in individual tiestalls with individual feed bins and bedded with sawdust. Cows were moved into the tiestall barn on $1 \mathrm{~d}$ per week and fed the control diet (Table 1) for at least $7 \mathrm{~d}$ beginning between 28 and $35 \mathrm{~d}$ before expected parturition. At $21 \mathrm{~d}$ before expected parturition, cows were assigned as described above to 1 of 2 treatment groups. The control $(\mathbf{C O N})$ diet was based on corn silage, wheat straw, and a concentrate mixture as commonly fed to prepartum cows in the northeast and Upper Midwest. The experimental (EXP) treatment consisted of the CON diet with the addition of synthetic zeolite A (X-Zelit, Protekta Inc., Lucknow, ON, Canada/Vilofoss, Graasten, Denmark) mixed into the TMR before feeding. Cows were fed their respective treatments until calving. After calving, all cows were fed the same postpartum diet (Table 1) and housed in tiestalls until 28 DIM, at which point the cows were moved to a freestall pen and fed the same diet until 63 DIM. The target study population was 50 cows and we assumed that 10 cows would be removed because of twinning or for health reasons. The sample size determination was based on biologically important differences in serum Ca concentrations between parturition and 2 DIM from previous work done by Leno et al. (2017). The detectable difference in Ca concentration between the 2 treatments was at least $0.20 \mathrm{mmol} / \mathrm{L}$, with $\alpha=0.05$ and $\beta=0.20$.

\section{Diet Formulation and Feeding Management}

Diets were formulated using the Cornell Net Carbohydrate and Protein System (CNCPS, version 6.5, Cornell University, Ithaca, NY). Ration ingredient composition and analyzed diet composition are presented in Table 1 and Table 2, respectively. The prepartum diets were identical with the exception of the addition of synthetic zeolite A to the EXP diet. Zeolite A was fed at $3.3 \%$ of DM, targeting $500 \mathrm{~g} / \mathrm{d}$ as fed. During the prepartum period, cows were fed daily between approximately 0900 and $1030 \mathrm{~h}$ with a targeted refusal rate of $5 \%$. During the postpartum period, cows were fed daily between 0700 and $0900 \mathrm{~h}$ with a targeted refusal rate of $10 \%$. Cows were individually fed and the weights of feed delivered and refused were recorded for intake measurements.

Weekly samples of TMR and individual feed ingredients were collected for determination of DM by drying in a forced-air oven for $96 \mathrm{~h}$ at $40^{\circ} \mathrm{C}$. The as-fed 
inclusion rates of the ration ingredients were adjusted weekly based on the DM values. Dried forages and TMR samples were ground to $2 \mathrm{~mm}$ in a Wiley mill (Arthur

Table 1. Ingredient composition of the prepartum diets and the common postpartum diet

\begin{tabular}{|c|c|c|c|}
\hline \multirow[b]{2}{*}{ Ingredient, $\%$ of DM } & \multicolumn{2}{|c|}{ Prepartum $^{1}$} & \multirow[b]{2}{*}{ Postpartum } \\
\hline & $\mathrm{CON}$ & EXP & \\
\hline Corn silage & 40.00 & 38.60 & 10.03 \\
\hline Corn silage & - & - & 30.22 \\
\hline Alfalfa hay & - & - & 3.58 \\
\hline Wheat straw & 33.33 & 32.17 & 4.48 \\
\hline Alfalfa silage & - & - & 10.74 \\
\hline Canola meal & 8.33 & 8.03 & 5.37 \\
\hline Ground shelled corn & - & - & 3.58 \\
\hline Steam-flaked corn & - & - & 6.27 \\
\hline Citrus pulp & 3.33 & 3.24 & 2.02 \\
\hline Blood meal & 1.67 & 1.62 & - \\
\hline Amino Plus ${ }^{2}$ & 6.67 & 6.47 & 6.14 \\
\hline Smartamine $\mathrm{M}^{3}$ & 0.03 & 0.05 & - \\
\hline LysAAmet $^{4}$ & - & - & 1.77 \\
\hline Soybean hulls & 5.00 & 4.85 & 3.74 \\
\hline Dried molasses & - & - & 4.08 \\
\hline X-Zelit ${ }^{5}$ & - & 3.40 & - \\
\hline Urea & - & - & 0.41 \\
\hline Megalac $\mathrm{R}^{6}$ & - & - & 0.91 \\
\hline DCAD Plus $^{7}$ & - & - & 0.82 \\
\hline MIN $\mathrm{AD}^{8}$ & - & - & 0.52 \\
\hline Salt & - & - & 0.50 \\
\hline Monocalcium phosphate & - & - & 0.20 \\
\hline Dicalcium phosphate & 0.43 & 0.42 & - \\
\hline Calcium carbonate & - & - & 0.20 \\
\hline Sodium bicarbonate & - & - & 1.63 \\
\hline Magnesium oxide & 0.07 & 0.07 & 0.25 \\
\hline Fermenten ${ }^{9}$ & - & - & 1.02 \\
\hline Celmanex ${ }^{10}$ & - & - & 0.61 \\
\hline Dynamate $^{11}$ & - & - & 0.52 \\
\hline Zinpro 4 Plex $\mathrm{C}^{12}$ & - & - & 0.23 \\
\hline Rumensin ${ }^{13}$ & 0.07 & 0.07 & 0.07 \\
\hline Vitamin E premix $^{14}$ & 0.03 & 0.03 & 0.05 \\
\hline Prefresh mineral mix ${ }^{15}$ & 1.00 & 0.97 & - \\
\hline
\end{tabular}

${ }^{1}$ Treatments: $\mathrm{CON}=$ control diet; $\mathrm{EXP}=$ control diet plus synthetic zeolite A.

${ }^{2}$ Heat-treated soybean meal; Ag Processing Inc. (Omaha, NE).

${ }^{3}$ DL-Met, physically protected with $\mathrm{pH}$-sensitive coating; Adisseo (Antony, France).

${ }^{4}$ Protein supplement; Perdue AgSolutions LLC (Salisbury, MD).

${ }^{5}$ Sodium aluminum silicate; Protekta Inc. (ON, Canada/Vilofoss, Graasten, Denmark).

${ }^{6}$ Rumen bypass fat; Church \& Dwight Co. Inc. (Princeton, NJ).

${ }^{7}$ Potassium carbonate; Church \& Dwight Co.

${ }^{8} \mathrm{Ca}-\mathrm{Mg}$ dolomite; Papillon Agricultural Company (Easton, MD).

${ }^{9}$ Rumen fermentation enhancer; Church \& Dwight Co. Inc.

${ }^{10}$ Yeast product; Church \& Dwight Co. Inc.

${ }^{11} \mathrm{~K} \mathrm{Mg}$ sulfate; The Mosaic Co. (Plymouth, MN).

${ }^{12}$ Trace mineral product; Zinpro Corp. (Eden Prairie, MN).

${ }^{13}$ Premix contained 26,400 g/t of monensin. Elanco Animal Health (Greenfield, IN).

${ }^{14}$ Contains $44,100 \mathrm{IU} / \mathrm{kg}$ of vitamin E.

${ }^{15}$ Contains 3,754 mg/kg Zn, $933 \mathrm{mg} / \mathrm{kg} \mathrm{Cu}, 4,658 \mathrm{mg} / \mathrm{kg} \mathrm{Mn}, 29 \mathrm{mg} /$ $\mathrm{kg}$ Se, $83 \mathrm{mg} / \mathrm{kg} \mathrm{Co}, 82 \mathrm{mg} / \mathrm{kg} \mathrm{I}, 1,174 \mathrm{kIU} / \mathrm{kg}$ vitamin A, $235 \mathrm{kIU} / \mathrm{kg}$ vitamin $\mathrm{D}$, and 11,658 $\mathrm{IU} / \mathrm{kg}$ vitamin $\mathrm{E}$.
H. Thomas, Philadelphia, PA). Samples of TMR were then composited at 4-wk intervals and feed ingredients were composited over the course of the study. Composited samples were submitted to a commercial laboratory (Cumberland Valley Analytical Services, Waynesboro, PA) for wet chemistry analysis as described by Leno et al. (2017). Results from analysis of composited forage samples were input into CNCPS v. 6.5 to determine predicted dietary MP concentrations.

\section{BW, BCS, Milk Sampling, and Energy Balance}

Body weight was measured and BCS (Edmonson et al., 1989) was assigned by 2 scorers, of which the average was used for statistical analysis, weekly for each cow starting the week before treatment assignment through 28 DIM. Rumination data were collected with HR tags (SCR Dairy, Netanya, Israel) in 2-h intervals from enrollment through 28 DIM. Daily rumination was calculated as the sum of each 2-h interval within a day. If a 2-h interval was missing, the entire day was recorded as missing. Cows were monitored through 150 DIM to evaluate time to pregnancy.

Colostrum was harvested within $2 \mathrm{~h}$ of calving, and colostrum weight, volume, and Brix (model \#300010, SPER Scientific, Scottsdale, AZ) were recorded by the Cornell University Ruminant Center staff. Samples were collected and stored at $4^{\circ} \mathrm{C}$ until transportation to Cornell University for analysis of IgG (turbidimetric assay) on an automated analyzer (Roche/Hitachi Modular P analyzer, Roche Diagnostics, Indianapolis, IN) at the Cornell University Animal Health Diagnostic Center (Ithaca, NY).

All cows were milked $3 \times / d$ at 0600, 1400, and 2200 h. Milk weights were recorded at each milking through 63 DIM, and daily milk yield was calculated as the sum of the 3 milk weights per day. Milk samples were collected weekly at 3 consecutive milkings from wk 1 through 4 of lactation and stored at $4^{\circ} \mathrm{C}$ until transportation to Cornell University within $72 \mathrm{~h}$ of collection for analysis. Milk fat, true protein, and anhydrous lactose content were determined using a Fourier transform mid-infrared (FTIR) spectrophotometer (Lactoscope model FTA, Delta Instruments, Drachten, the Netherlands). The prediction models used were the optimized basic model filter wavelengths and intercorrection factors described by Kaylegian et al. (2009). Calibration of the FTIR for measurement of fat, true protein, and anhydrous lactose was done using a 14-sample modified milk calibration set (Kaylegian et al., 2006) produced monthly. The reference chemistry values were an alllaboratory mean produced by a network of 10 to 12 laboratories running all samples with the reference methods (Wojciechowski et al., 2016). The reference 
methods for fat, true protein, and anhydrous lactose measurements were determined in duplicate in each laboratory using the following validated methods (AOAC International, 2000): fat by modified Mojonnier ether extraction (method 989.05), true protein by Kjeldahl analysis (method 991.22), lactose by enzymatic analysis (method 2006.06), and total solids by atmospheric forced-air oven drying (method 990.20). Milk SCC was measured using a fluorometric flow cytometry method using 4',6-diamidino-2-phenylindole as the staining dye (SomaSmart/Delta Instruments). Calibration of the milk somatic cell counter was done using calibration samples from the USDA Federal Milk Markets with reference values established using the direct microscopic SCC method (Fitts and Laird, 2004).

De novo, mixed-origin, and preformed milk fatty acids were measured directly (in $\mathrm{g} / 100 \mathrm{~g}$ of milk) by FTIR using the partial least squares (PLS) prediction models described by Woolpert et al. (2016). Gas-liquid chromatography reference chemistry for calibration of the milk fatty acid parameters was as described by Wojciechowski and Barbano (2016). The milk fatty acid calibration sample set was the same 14-sample set that was used for calibration of the main milk components. The calibration concentration ranges for de novo, mixed-origin, and preformed milk fatty acids were 0.05 to $1.4 \mathrm{~g} / 100 \mathrm{~g}$ of milk, 0.08 to $2.2 \mathrm{~g} / 100 \mathrm{~g}$ of milk, and 0.06 to $1.9 \mathrm{~g} / 100 \mathrm{~g}$ of milk, respectively. Milk urea $\mathrm{N}$ was measured by FTIR using a PLS model developed by Delta Instruments (parameter number 502) and was calibrated using reference chemistry values from an enzymatic MUN assay (Megazyme, kit K-URAMR, Bray, Co. Wicklow, Ireland).

Somatic cell scores were calculated using the equation from Shook (1993): SCS $=\log _{2}(\mathrm{SCC} / 100,000)+3$. The milk yield at each milking was used to weight the milk composition for the day and to calculate yields of milk fat, protein, lactose, and TS. Weekly ECM [ECM $=(0.327 \times \mathrm{kg}$ of average weekly milk yield $)+(12.95$ $\times \mathrm{kg}$ of fat $)+(7.65 \times \mathrm{kg}$ of true protein $)$; Tyrrell and Reid, 1965] and $3.5 \% \mathrm{FCM}[3.5 \% \mathrm{FCM}=(0.432 \times \mathrm{kg}$ of average weekly milk yield $)+(16.216 \times \mathrm{kg}$ of fat $)$; Gaines and Davidson, 1923] were calculated using the average weekly milk yield and weekly milk composition.

Table 2. Analyzed nutrient composition (mean $\pm \mathrm{SD} ; \%$ of DM unless otherwise noted) for the control prepartum diet $(\mathrm{CON})$, the experimental diet (EXP; the control prepartum diet with the addition of synthetic zeolite A), and the common postpartum diet

\begin{tabular}{|c|c|c|c|}
\hline \multirow[b]{2}{*}{ Nutrient $^{1}$} & \multicolumn{2}{|c|}{ Prepartum $^{2}$} & \multirow[b]{2}{*}{ Postpartum } \\
\hline & $\mathrm{CON}$ & EXP & \\
\hline DM, $\%$ of as fed & $46.9 \pm 2.2$ & $48.0 \pm 2.4$ & $45.5 \pm 2.2$ \\
\hline $\mathrm{CP}$ & $13.6 \pm 1.0$ & $13.5 \pm 0.7$ & $16.4 \pm 0.4$ \\
\hline $\mathrm{ADF}$ & $29.8 \pm 1.1$ & $29.0 \pm 1.0$ & $18.8 \pm 1.3$ \\
\hline $\mathrm{NDF}$ & $46.4 \pm 1.4$ & $46.0 \pm 1.7$ & $30.6 \pm 2.8$ \\
\hline Lignin & $4.5 \pm 0.2$ & $4.5 \pm 0.2$ & $2.6 \pm 0.5$ \\
\hline Starch & $16.8 \pm 1.7$ & $16.3 \pm 0.3$ & $26.1 \pm 1.6$ \\
\hline Sugar & $3.2 \pm 0.8$ & $3.3 \pm 0.4$ & $3.3 \pm 0.5$ \\
\hline $\mathrm{NFC}$ & $32.9 \pm 1.4$ & $31.5 \pm 0.6$ & $43.3 \pm 2.6$ \\
\hline Fat & $2.24 \pm 0.13$ & $2.25 \pm 0.30$ & $2.64 \pm 0.24$ \\
\hline Ash & $6.12 \pm 0.53$ & $7.99 \pm 0.36$ & $9.14 \pm 0.49$ \\
\hline $\mathrm{Ca}$ & $0.68 \pm 0.05$ & $0.65 \pm 0.03$ & $1.00 \pm 0.07$ \\
\hline $\mathrm{P}$ & $0.39 \pm 0.03$ & $0.38 \pm 0.02$ & $0.38 \pm 0.01$ \\
\hline $\mathrm{Mg}$ & $0.42 \pm 0.05$ & $0.42 \pm 0.03$ & $0.51 \pm 0.04$ \\
\hline $\mathrm{K}$ & $1.14 \pm 0.06$ & $1.12 \pm 0.04$ & $1.91 \pm 0.11$ \\
\hline $\mathrm{S}$ & $0.25 \pm 0.00$ & $0.24 \pm 0.01$ & $0.46 \pm 0.04$ \\
\hline $\mathrm{Na}$ & $0.14 \pm 0.03$ & $0.50 \pm 0.04$ & $0.82 \pm 0.04$ \\
\hline $\mathrm{Cl}$ & $0.31 \pm 0.03$ & $0.30 \pm 0.03$ & $0.53 \pm 0.03$ \\
\hline $\mathrm{DCAD}, \mathrm{mEq} / 100 \mathrm{~g}$ of $\mathrm{DM}$ & $11.03 \pm 2.06$ & $26.87 \pm 1.71$ & $40.75 \pm 2.54$ \\
\hline $\mathrm{NE}_{\mathrm{L}}, \mathrm{Mcal} / \mathrm{kg}$ & $1.46 \pm 0.02$ & $1.43 \pm 0.01$ & $1.60 \pm 0.03$ \\
\hline $\mathrm{MP}^{2} \mathrm{~g} / \mathrm{kg}$ of $\mathrm{DM}$ & 87.24 & 85.41 & 123.04 \\
\hline $\mathrm{MP}^{3}$ intake, $\mathrm{g} / \mathrm{d}$ & 1,274 & 1,196 & 2,689 \\
\hline
\end{tabular}

${ }^{1}$ Weekly TMR samples were composited over 4-wk intervals for chemical analysis. Five composites for the CON diet, 4 composites for the EXP diet, and 5 composites for the postpartum diet were analyzed. Nutrients are reported as a \% of DM, unless noted.

${ }^{2}$ Metabolizable protein content as predicted by the Cornell Net Carbohydrate and Protein System (v. 6.5, Cornell University, Ithaca, NY) based on analyzed forage composition.

${ }^{3}$ Based on actual intakes during the prepartum (21 d) and postpartum (28 d) period and predicted diet MP concentration. 
Energy-corrected milk and average weekly DMI were used to evaluate milk production efficiency (milk production efficiency $=\mathrm{kg}$ of $\mathrm{ECM} / \mathrm{kg}$ of average weekly DMI).

Weekly energy balance (EBAL) for the prepartum and postpartum period were calculated in accordance with NRC (2001) equations. Prepartum EBAL was determined with the following equation:

Prepartum $\mathrm{NE}_{\mathrm{L}}(\mathrm{Mcal} / \mathrm{d})$ balance = energy intake

(Mcal of $\mathrm{NE}_{\mathrm{L}} / \mathrm{d}$ ) - [maintenance requirement

(Mcal of $\left.\mathrm{NE}_{\mathrm{L}} / \mathrm{d}\right)+$ pregnancy requirement

(Mcal of $\left.\mathrm{NE}_{\mathrm{L}} / \mathrm{d}\right)$ ],

and postpartum EBAL was determined with the following equation:

Postpartum $\mathrm{NE}_{\mathrm{L}}(\mathrm{Mcal} / \mathrm{d})$ balance $=$ energy intake

(Mcal of $\mathrm{NE}_{\mathrm{L}} / \mathrm{d}$ ) - [maintenance requirement

(Mcal of $\mathrm{NE}_{\mathrm{L}} / \mathrm{d}$ ) + lactation requirement

(Mcal of $\left.\mathrm{NE}_{\mathrm{L}} / \mathrm{d}\right)$ ],

where energy intake (Mcal of $\mathrm{NE}_{\mathrm{L}} / \mathrm{d}$ ) = weekly DMI average $(\mathrm{kg} / \mathrm{d}) \times \operatorname{diet} \mathrm{NE}_{\mathrm{L}}(\mathrm{Mcal} / \mathrm{kg}$ of $\mathrm{DM})$; maintenance requirement $(\mathrm{Mcal})=$ weekly metabolic $\mathrm{BW}$ $\left(\mathrm{kg}^{0.75}\right) \times 0.08\left(\mathrm{Mcal} / \mathrm{kg}^{0.75}\right.$ per day); pregnancy requirement $($ Mcal $)=(0.00318 \times \mathrm{d}$ of gestation -0.0352$)$ $\times(1 / 0.218)$; and lactation requirement $(\mathrm{Mcal} / \mathrm{d})=$ weekly average milk yield $(\mathrm{kg} / \mathrm{d}) \times[(0.0929 \times$ fat percentage $)+(0.0563 \times$ true protein percentage $)+$ $(0.0395 \times$ lactose percentage $)]$.

\section{Blood Sampling, Disease, and Treatment}

Blood samples were collected between 0600 and 0730 $\mathrm{h}$ from the coccygeal vessels $1 \times /$ wk (Monday) from enrollment until $7 \mathrm{~d}$ before expected calving, daily from $7 \mathrm{~d}$ before expected calving through 7 DIM with 2 samples collected within $24 \mathrm{~h}$ following parturition, and then $3 \times /$ wk (Monday, Wednesday, and Friday) thereafter through 28 DIM. Samples were collected using 20-gauge Vacutainer needles (Greiner Bio-One GmbH, Kremsmuenster, Austria; Exelint International, Co., Redondo Beach, CA); one 10-mL sodium heparin (158 USP) and one 10-mL plain evacuated tube (Becton Dickinson and Co., Franklin Lakes, NJ) were collected at each sampling time for separation of plasma and serum, respectively. Blood collected in sodium heparin tubes was placed immediately on ice and plasma was harvested after centrifugation at 2,000 $\times g$ for $20 \mathrm{~min}$ at $4^{\circ} \mathrm{C}$. Serum tubes were allowed to clot for at least 30 min at room temperature before centrifugation at 2,000 $\times g$ for $15 \mathrm{~min}$ at $20^{\circ} \mathrm{C}$. After centrifugation, plasma and serum were aliquotted into $1.7-\mathrm{mL}$ microfuge tubes, snap frozen in liquid $\mathrm{N}_{2}$, and stored at $-20^{\circ} \mathrm{C}$ until analysis. One aliquot of plasma was transported immediately to Cornell University after snap freezing to be stored at $-80^{\circ} \mathrm{C}$ until analysis of oxidant status (within 3 mo of collection).

Cows were observed daily by farm and research personnel throughout the duration of the study for health disorders. Briefly, cows were monitored for displaced abomasum; retained placenta, defined as failure to pass the fetal membranes within $24 \mathrm{~h}$ after parturition; hyperketonemia, defined as BHB $\geq 1.2 \mathrm{mmol} / \mathrm{L}$ (McArt et al., 2013); mastitis; metritis; respiratory disorders; and hypocalcemia. If a cow showed signs of clinical hypocalcemia such as dullness, lethargy, muscle weakness, wobbly appearance, cold ears and dry muzzle, abstinence from eating with no or reduced rumen contractions, or lying down with the head turned toward the flank, a blood sample was taken and serum mineral status was evaluated by farm personnel using an on-farm electrolyte analyzer (VetScan VS2, Abaxis Inc., Union City, CA). Treatment with intravenous Ca was justified if total Ca was $\leq 1.375 \mathrm{mmol} / \mathrm{L}$ or if total Ca was $>1.375$ $\mathrm{mmol} / \mathrm{L}$ and the cow was showing multiple signs of hypocalcemia. If $\mathrm{Ca}$ was within normal ranges but $\mathrm{P}$, $\mathrm{Mg}$, or both were considered low, cows were treated with $\mathrm{P}, \mathrm{Mg}$, or both. An additional blood sample was taken before $\mathrm{Ca}, \mathrm{P}$, or $\mathrm{Mg}$ treatment for analysis at the Cornell University Animal Health Diagnostic Center (Ithaca, NY) to confirm farm treatment.

\section{Analytical Methods}

A subset of serum samples and the pretreatment serum samples were analyzed for Ca (colorimetric assay), $\mathrm{P}$ (photometric endpoint method), and $\mathrm{Mg}$ (colorimetric endpoint method) concentrations with an automated analyzer (Roche/Hitachi Modular P analyzer, Roche Diagnostics) at the Cornell University Animal Health Diagnostic Center (Ithaca, NY). The 4 serum samples analyzed between calving and 3 DIM were classified as normal $\mathrm{Ca}(\mathrm{Ca} \geq 2.125 \mathrm{mmol} / \mathrm{L})$ or low $\mathrm{Ca}$ $(\mathrm{Ca}<2.125 \mathrm{mmol} / \mathrm{L}$; Goff, 2008). As in Caixeta et al. (2017), cows were classified retrospectively as having eucalcemia ( 0 samples with $\mathrm{Ca}<2.125 \mathrm{mmol} / \mathrm{L}$ ), subclinical hypocalcemia (SCH; 1 to 3 samples with $\mathrm{Ca}$ $<2.125 \mathrm{mmol} / \mathrm{L}$ ), or chronic subclinical hypocalcemia (cSCH; 4 samples with $\mathrm{Ca}<2.125 \mathrm{mmol} / \mathrm{L}$ ) between calving and 3 DIM. A subset of plasma samples stored at $-80^{\circ} \mathrm{C}$ were analyzed for oxidant status according to 
Abuelo et al. (2016). To accurately evaluate oxidative stress between the treatment groups, the presence of pro-oxidants and antioxidants needs to be measured (Celi, 2011; Abuelo et al., 2015). The pro-oxidant presence in plasma was quantified using a commercially available assay (ROS and RNS assay, Cell Biolabs, San Diego, CA) to measure reactive oxygen and nitrogen species (RONS) per the manufacturer's directions. A 5-point dichlorodihydrofluorescein standard curve plus a zero standard was used to fit the data to determine the RONS concentration. The reported values represent relative fluorescent units. The inter- and intraassay coefficients of variation $(\mathbf{C V})$ were 16.6 and $8.1 \%$, respectively. Because it is difficult to measure individual antioxidants, we used an approach to measure the total antioxidant capacity (Celi, 2011). The antioxidant potential (AOP) was assessed by the reduction of a radical $\left[2,2^{\prime}\right.$ azino-bis(3-ethylbenzothiazoline-6-sulfonic acid); Sigma-Aldrich, St. Louis, MO] as described by Re et al. (1999) and Abuelo et al. (2016). A 5-point standard curve plus a zero standard was prepared with Trolox (Sigma-Aldrich), a known antioxidant standard. The standard curve was used to fit the data to determine the antioxidant activity of the sample. The interand intraassay CV were 15.5 and $9.0 \%$, respectively. To assess oxidative stress during the transition period, the oxidant status index $(\mathbf{O S i}$; OSi $=$ RONS/AOP) was evaluated because it reflects the changes in redox balance (Abuelo et al., 2013, 2016). For interpretation purposes, a greater OSi indicates a greater risk of oxidative stress.

\section{Statistical Analysis}

Prepartum and postpartum data were analyzed separately. Prepartum data were restricted to the $3 \mathrm{wk}$ before calving. Because of the blood sampling scheme, the average day relative to calving is reported. Daily DMI, milk production, and rumination were condensed to weekly averages for statistical analysis. All statistical analyses were conducted with SAS (version 9.4, SAS Institute Inc., Cary, NC). Descriptive statistics were calculated using the FREQ and MEANS procedures in SAS.

The distribution of parity and prevalence of health events, hypocalcemia, and chronic hypocalcemia between treatments were tested with a Fisher's exact test using PROC FREQ. Previous lactation 305-d matureequivalent milk production, days on treatment, and covariate measures of BW, BCS, DMI, EBAL, and rumination were tested by ANOVA using PROC MIXED with the fixed effect of treatment. Continuous measures not repeated over time were subjected to ANOVA using the MIXED procedure with fixed effects of treatment, parity group, and the interaction between treatment and parity group. Data analyzed over time were subjected to repeated-measures ANOVA using the MIXED procedure and the repeated statement for time. Fixed effects included in the model were treatment, time, parity group, and all 2-way interactions with the random effect of cow within treatment. If available, covariate measures collected during the week before treatment assignment were included in all prepartum models and were only included in postpartum models if the covariate measure was significant $(P \leq 0.05)$. Previous $305-\mathrm{d}$ mature-equivalent milk production was included as the covariate measure for the milk yield analysis. $P$-values were corrected for multiple comparisons using Tukey honestly significant difference test, and the KenwardRoger method was used for estimation of denominator degrees of freedom. Four covariance structures were tested with each model and the structure resulting in the lowest Akaike's information criterion was selected. For repeated-measures data with unequal timing between measurements (blood measurements), the compound symmetry, heterogeneous compound symmetry, firstorder antedependence, and unstructured covariance structures were tested. For repeated measures with equal timing between measurements, compound symmetry, heterogeneous compound symmetry, autoregressive order 1 , and heterogeneous autoregressive order 1 covariance structures were tested. Plots of studentized residuals were visually inspected for homogeneity and normality of variance. If non-normality existed, data were log-transformed (RONS and OSi) or extreme outliers were removed and the analysis was repeated.

The effect of treatment and hypocalcemia status (both with the fixed effect of parity) on time to pregnancy by 150 DIM were analyzed by a Cox proportional hazards model using the PHREG procedure. Cows that died or were sold before the end of the voluntary waiting period of $63 \mathrm{~d}$ were removed from the analysis because they were not eligible to become pregnant. Cows that were not pregnant, sold, or died between the end of the voluntary waiting period and 150 DIM were rightcensored.

Least squares means and standard errors or geometric means and 95\% confidence intervals are reported throughout. Significance was declared at $P \leq 0.05$ and trends are discussed at $0.05<P \leq 0.10$.

\section{RESULTS}

\section{Study Population and Treatment Diets}

The chemical composition was very similar between the CON and EXP diets (Tables 1 and 2). With the addition of zeolite $\mathrm{A}$ in the EXP diet, we did observe 
Table 3. Distribution of parity and means $( \pm$ SD) for previous lactation 305-d mature-equivalent (MEq) milk production, days on treatment diets, BW, BCS, DMI, rumination, and energy balance (EBAL) at enrollment or during the covariate period

\begin{tabular}{lccc}
\hline & \multicolumn{2}{c}{ Treatment $^{1}$} \\
\cline { 2 - 3 } Variable & CON & EXP \\
\hline Entering parity: & 13 & 11 & 0.85 \\
2 & 16 & 15 & 0.54 \\
$\geq 3$ & $14,870 \pm 2,081$ & $15,197 \pm 1,793$ & 0.47 \\
Previous 305-d MEq, kg & $22 \pm 5$ & $21 \pm 5$ & 0.97 \\
Days on treatment & $777 \pm 92$ & $776 \pm 68$ & 0.62 \\
BW, kg & $3.25 \pm 0.24$ & $15.29 \pm 0.27$ & 0.87 \\
BCS & $15.1 \pm 2.0$ & $521 \pm 43$ & 0.71 \\
DMI, kg/d & $515 \pm 65$ & $6.96 \pm 1.88$ & 0.64 \\
Rumination, min/d & $6.85 \pm 2.66$ & & \\
EBAL, Mcal/d & &
\end{tabular}

${ }^{1} \mathrm{CON}=$ control diet; $\mathrm{EXP}=$ control diet plus synthetic zeolite A.

a slight dilution effect, except for an increased Na content due to the composition of zeolite A.

We removed data from 5 cows before analysis, with decisions made by a researcher blinded to treatment. These included 4 cows that calved with twins (CON $=1 ; \mathrm{EXP}=3$ ) and $1 \mathrm{cow}$ assigned to EXP that was diagnosed with toxic mastitis postpartum. Data were also removed for 3 cows fed EXP after 5, 16, or 29 DIM due to injury. The final data set included 55 cows, of which 29 were in the CON group and 26 were in the EXP group. The description of the treatment group populations before treatment assignment and after exclusion of the cows that calved with twins or had toxic mastitis, including parity, previous lactation 305-d mature-equivalent milk yield, days on treatment, BW, BCS, DMI, EBAL, and rumination, is presented in Table 3. We did not observe treatment differences in any of these measurements. There were no significant treatment differences between OSi and serum concentrations of $\mathrm{Ca}, \mathrm{P}$, and $\mathrm{Mg}$ taken during the covariate week (data not shown).

\section{Serum Mineral Concentrations and Plasma Oxidative Stress Indices}

Serum mineral concentrations and oxidative stress indices for cows fed the different prepartum diets are presented in Table 4, and treatment by day effects are presented in Figure 1 for serum Ca, P, and Mg. Cows fed EXP during the prepartum period had higher serum Ca concentrations, most notably during the periparturient period. Serum P concentrations in the EXP-fed cows were approximately half that of CON-fed cows during the entire prepartum period. During the immediate postpartum period, serum $\mathrm{P}$ was lower in the EXP-fed cows but increased through 14 DIM such that cows fed the EXP diet had higher serum $\mathrm{P}$ concentrations at 14 DIM than CON-fed cows. Serum Mg concentrations decreased steadily during the prepartum period for EXP-fed cows, whereas cows fed the CON diet had relatively constant $\mathrm{Mg}$ concentrations. Cows fed the EXP diet had markedly lower serum Mg concentrations within the first day postpartum but we did not observe any treatment by day interactions thereafter. Effects of treatment on indices of oxidant status (RONS, AOP, and $\mathrm{OSi}$ ) were not significant during the prepartum or postpartum periods.

\section{Hypocalcemia}

Subclinical hypocalcemia prevalence for the 2 treatment groups at different time points is presented in Figure 2A. Three times as many CON-fed cows had serum Ca concentrations $<2.125 \mathrm{mmol} / \mathrm{L}$ within 1 DIM compared with the EXP-fed cows. The greatest prevalence of SCH occurred within 1 DIM for both treatment groups. The CON-fed cows had a greater prevalence of SCH from $3 \mathrm{~d}$ before calving through 3 DIM $(P<$ $0.05)$.

Fourteen of 55 cows were categorized as not having $\mathrm{SCH}$ from calving through $3 \mathrm{DIM}$; only one of these cows were in the CON-fed group. The other $50 \%$ (n $=13)$ of EXP-fed cows and $62 \%(\mathrm{n}=18)$ of CONfed cows were categorized as having $\mathrm{SCH}$. We did not observe any EXP-fed cows to have cSCH, whereas $34 \%$ $(\mathrm{n}=10)$ of CON-fed cows were categorized as having cSCH (Figure 2B).

\section{$D M I, E B A L$, Rumination, BW, and BCS}

Prepartum and postpartum DMI, EBAL, rumination, $\mathrm{BW}$, change in BW, and BCS are presented in Table 
5. We observed a treatment by week effect for DMI such that intakes were similar between treatments at 3 wk before parturition but EXP-fed cows had a greater reduction in DMI as parturition approached (Figure 3); however, the multiple comparison results indicated no treatment differences in any individual week during the prepartum period. During the postpartum period, we did not observe any treatment or treatment by week effects on DMI. Cows fed the EXP diet ruminated for less time per day than cows fed the CON diet (500 vs. 521 $\min / \mathrm{d} ; P=0.03)$ with no treatment or treatment by week effects during the postpartum period. We observed a treatment by parity trend for postpartum rumination such that there was no difference between parity groups for EXP-fed cows $(P=0.98)$; however, within the CON treatment, second lactation and greater ruminated for longer per day than third lactation and greater cows (542 vs. $481 \mathrm{~min} / \mathrm{d} ; P=0.02$ ). Cows fed the EXP diet did not gain as much BW as calving approached compared with CON-fed cows, and no treatment effects were observed during the postpartum period. Prepartum BCS was lower in EXP-fed cows; however, the absolute differences were small $(P<0.01)$. There was a treatment by week effect on postpartum BCS $(P=$ 0.01 ) such that EXP-fed cows had a numerically lower BCS than cows fed CON during wk 1 and 3 but did not differ in wk 2 and 4 . The multiple comparison results indicated no treatment differences in any week during the postpartum period for BCS.

\section{Colostrum, Milk Yield, and Milk Composition}

Colostrum measurements along with postpartum milk yield and composition are presented in Table 6 . We detected no differences in colostrum parameters between cows fed the EXP diet and cows fed the CON diet. Milk yield, FCM, ECM, and feed efficiency (ECM/DMI) were not different between the 2 treatments; however, we observed a tendency for EXP-fed cows to have greater protein $(3.30$ vs. $3.19 \% ; P=0.09)$ and total solids (13.32 vs. $13.03 \% ; P=0.07)$ concentrations in milk and lower MUN concentrations (10.90 vs. $12.46 \mathrm{mg} / \mathrm{dL} ; P=0.01$ ) from wk 1 through 4 . We did not observe a difference between treatments for fat $(P$ $=0.35)$, protein $(P=0.33)$, lactose $(P=0.67)$, or total solids $(P=0.65)$ yield. There was a treatment by week effect for milk fat concentration such that cows fed EXP prepartum had a higher fat concentration during wk 3 and 4 relative to calving, although the multiple comparisons analysis did not yield significant differences between treatment groups during either week.

We observed no treatment, treatment by week, or treatment by parity effects for de novo fatty acids (FA). A treatment by parity trend was observed for the mixed FA milk concentration $(P=0.07)$ such that there was no difference between parity groups for cows fed the EXP $\operatorname{diet}(P=0.94)$; however, within the CON treatment, second-lactation cows had a higher mixed FA milk content than third-lactation and greater cows

Table 4. Least squares means (SE) or geometric means (back-transformed 95\% CI) for prepartum and postpartum serum mineral concentrations and oxidative stress indices for multiparous cows fed a control prepartum diet (CON) or a control prepartum diet with the addition of synthetic zeolite A (EXP)

\begin{tabular}{|c|c|c|c|c|c|}
\hline \multirow[b]{2}{*}{ Variable } & \multicolumn{2}{|c|}{ Treatment } & \multirow[b]{2}{*}{ SEM } & \multicolumn{2}{|c|}{$P$-value ${ }^{1}$} \\
\hline & $\mathrm{CON}$ & EXP & & $\mathrm{T}$ & $\mathrm{T} \times \mathrm{D}$ \\
\hline \multicolumn{6}{|l|}{ Prepartum } \\
\hline $\mathrm{Ca}, \mathrm{mmol} / \mathrm{L}$ & 2.31 & 2.47 & 0.03 & $<0.001$ & 0.06 \\
\hline $\mathrm{P}, \mathrm{mmol} / \mathrm{L}$ & 2.03 & 1.03 & 0.04 & $<0.001$ & 0.04 \\
\hline $\mathrm{Mg}, \mathrm{mmol} / \mathrm{L}$ & 0.92 & 0.85 & 0.02 & $<0.01$ & $<0.01$ \\
\hline $\mathrm{AOP}^{2}$ & 53.82 & 51.60 & 1.76 & 0.36 & 0.47 \\
\hline $\mathrm{RONS}^{3}$ & 71.01 & 68.52 & 1.66 & 0.28 & 0.70 \\
\hline $\mathrm{OSi}^{4}$ & $1.33(1.24-1.44)$ & $1.34(1.24-1.45)$ & & 0.93 & 0.60 \\
\hline \multicolumn{6}{|l|}{ Postpartum } \\
\hline $\mathrm{Ca}, \mathrm{mmol} / \mathrm{L}$ & 2.15 & 2.33 & 0.02 & $<0.001$ & $<0.001$ \\
\hline $\mathrm{P}, \mathrm{mmol} / \mathrm{L}$ & 1.39 & 1.19 & 0.04 & $<0.001$ & $<0.001$ \\
\hline $\mathrm{Mg}, \mathrm{mmol} / \mathrm{L}$ & 0.92 & 0.91 & 0.01 & 0.51 & $<0.001$ \\
\hline AOP & 50.30 & 50.58 & 1.50 & 0.89 & 0.64 \\
\hline RONS & 49.51 & 50.43 & 1.93 & 0.73 & 0.40 \\
\hline $\mathrm{OSi}$ & $0.97(0.90-1.05)$ & 0.99 (0.91-1.07) & & 0.77 & 0.33 \\
\hline
\end{tabular}

${ }^{1} \mathrm{~T}=$ treatment; $\mathrm{D}=$ day.

${ }^{2} \mathrm{AOP}=$ antioxidant potential, expressed as sample antioxidant concentration, determined by the capacity of the sample to inhibit 2,2'-azinobis-(3-ethylbenxothiazoline-6-sulfonic acid) radical, relative to Trolox (SigmaAldrich, St. Louis, MO).

${ }^{3} \mathrm{RONS}=$ reactive oxygen and nitrogen species, expressed as relative fluorescent units $(\mathrm{RFU}) / \mu \mathrm{L}$.

${ }^{4} \mathrm{OSi}=$ oxidant status index, calculated as RONS/AOP. 

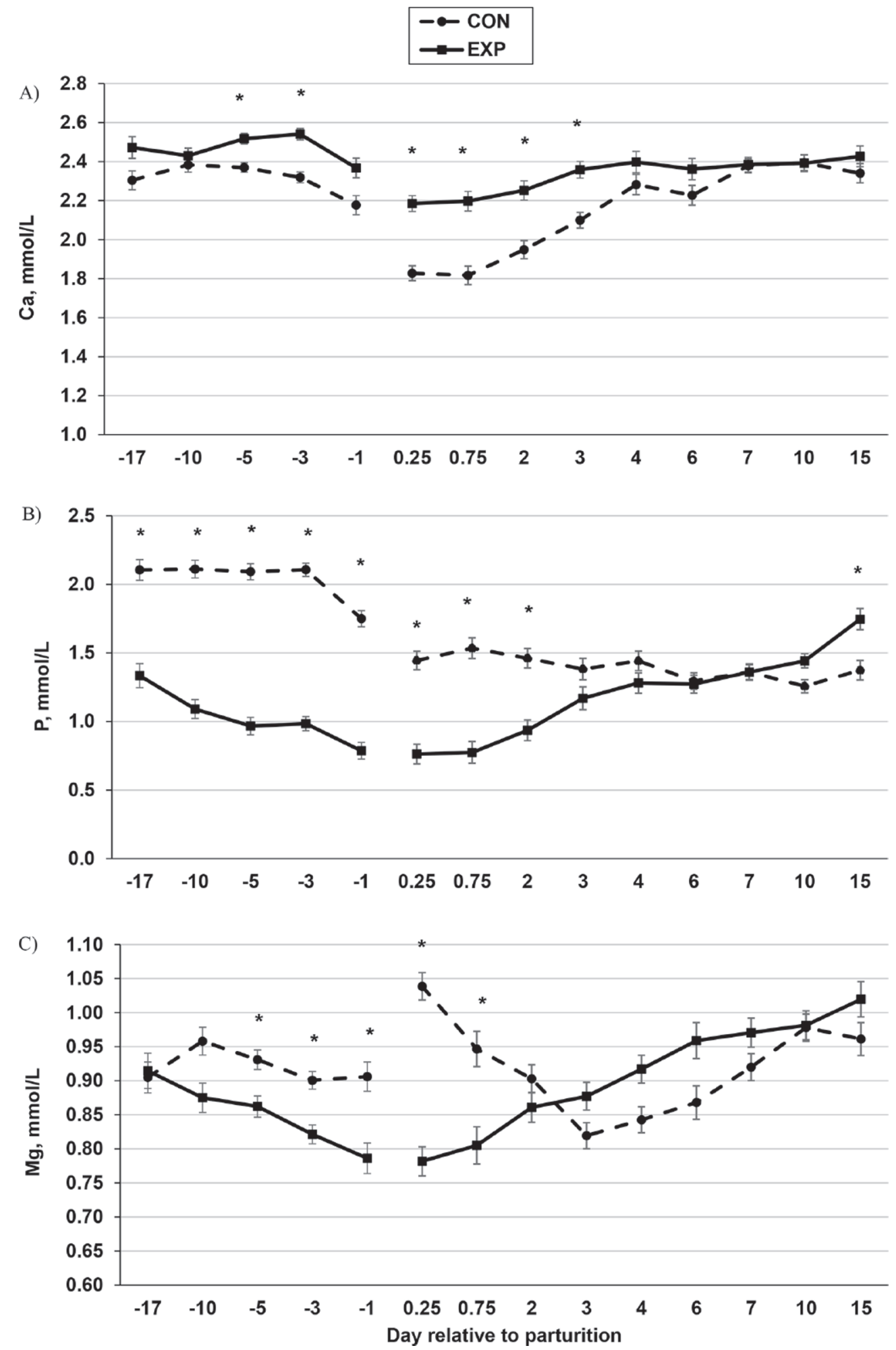

Figure 1. Least squares means and SE for prepartum and postpartum serum (A) Ca (mmol/L), (B) P (mmol/L), and (C) Mg (mmol/L) for multiparous cows fed a control prepartum diet (CON) or a control prepartum diet with the addition of synthetic zeolite A (EXP). Prepartum and postpartum data were analyzed separately. There was a treatment effect $(P<0.001)$ and treatment by day effect $(P=0.06)$ during the prepartum period and a treatment by day effect $(P<0.001)$ during the postpartum period for serum Ca. There was a treatment by day effect during the prepartum $(P=0.04)$ and postpartum $(P<0.001)$ period for serum $\mathrm{P}$. A treatment by day effect was observed during the prepartum period $(P<0.01)$ and postpartum period $(P<0.001)$ for serum $\mathrm{Mg} .{ }^{*}$ Treatment by day effects at time points when treatment means differed significantly $(P \leq 0.05)$. 

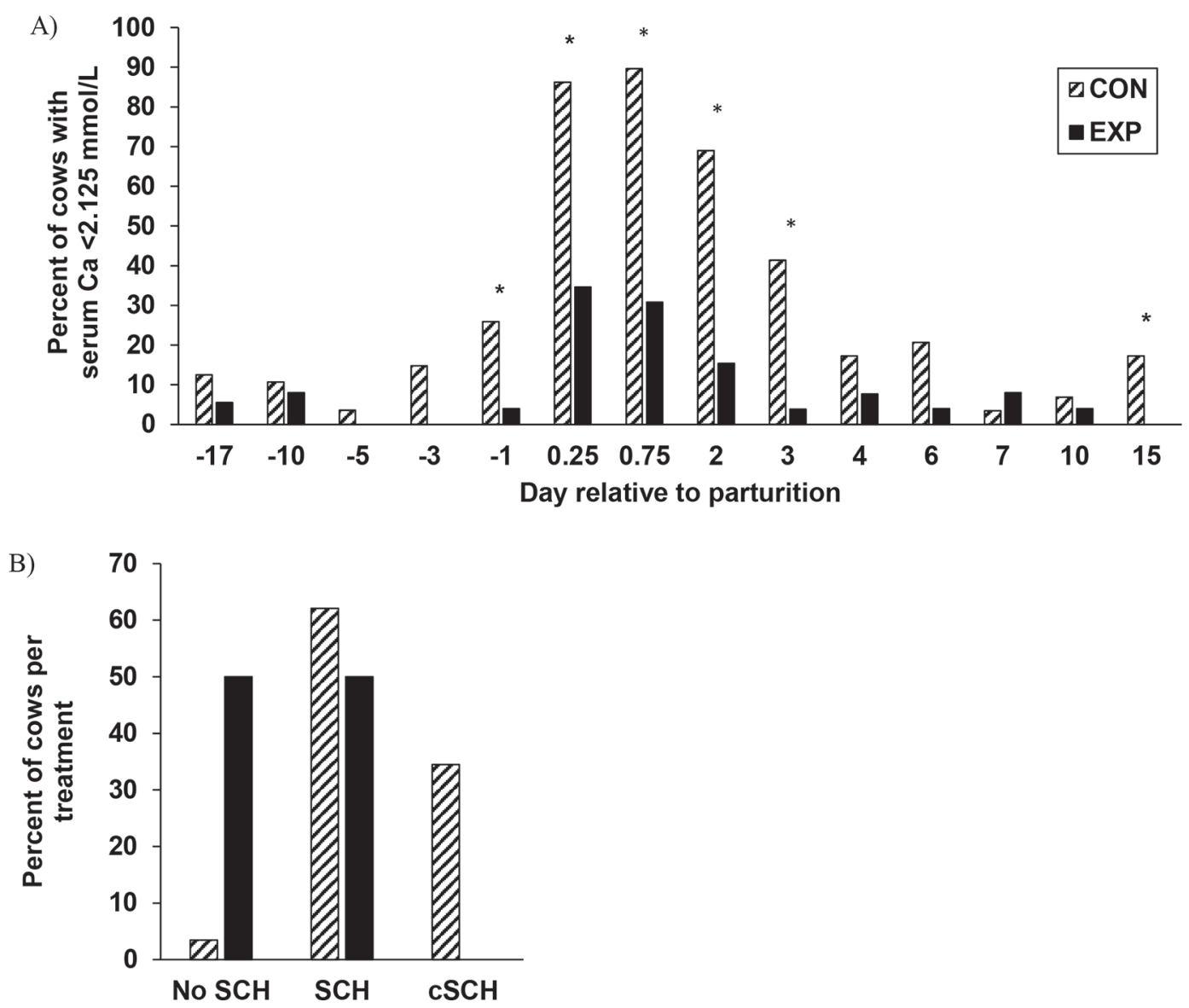

Figure 2. (A) Prevalence of subclinical hypocalcemia $(\mathrm{Ca}<2.125 \mathrm{mmol} / \mathrm{L})$ at different time points for multiparous cows fed a control prepartum diet $(\mathrm{CON})$ or a control prepartum diet with the addition of synthetic zeolite A $(\mathrm{EXP}) .{ }^{*}$ Days at which treatment effects differed $(P$ $\leq 0.05)$. (B) Proportion of cows with hypocalcemia, categorized by severity. Cows were classified based on the number of serum samples with $\mathrm{Ca}<2.125 \mathrm{mmol} / \mathrm{L}$, acquired from parturition through 3 DIM. Cows were eucalcemic (no SCH) if 0 samples were $<2.125 \mathrm{mmol} / \mathrm{L}$, subclinical hypocalcemic ( $\mathrm{SCH}$ ) if 1 to 3 samples were $<2.125 \mathrm{mmol} / \mathrm{L}$, and chronic subclinical hypocalcemic $(\mathrm{cSCH})$ is all 4 samples were $<2.125 \mathrm{mmol} / \mathrm{L}$. The proportion of cows with hypocalcemia differed between the cows fed CON and EXP $(P<0.0001)$.

(1.43 vs. $1.20 \mathrm{~g} / 100 \mathrm{~g}$ of milk; $P<0.01)$. For cows in third lactation and greater, cows fed the EXP diet had a larger mixed FA proportion of FA than CON-fed cows (35.2 vs. $31.7 \% ; P=0.03$ ). Cows fed the EXP diet tended to have a higher mixed FA yield than CON-fed cows. We also found a treatment by week effect for the preformed FA (g/100 g of milk, g/100 g of FA, and $\mathrm{g} / \mathrm{d}$ ); however, the multiple comparisons analysis did not yield significant differences between treatment groups during any individual week $(P>0.59)$. A treatment by parity effect was observed for the preformed FA as a proportion of FA $(P=0.04)$ such that there was no difference between parity groups for cows fed the EXP diet $(P=0.91)$; however, within the CON treatment, second-lactation cows had higher preformed FA (g/100 g of FA) than third-lactation and greater cows (48.4 vs. $41.3 \mathrm{~g} / 100 \mathrm{~g}$ of $\mathrm{FA} ; P<0.01$ ).

\section{Health Disorders and Reproductive Performance}

Farm-determined health disorder incidence is reported in Table 7. Because of the small population of cows in the study, caution should be used when interpreting these results. Cows fed EXP tended to have a greater displaced abomasum incidence $(P=0.06)$ and cows fed CON tended to have a greater clinical mastitis incidence $(P=0.09)$. Notably, we observed no cases of milk fever involving recumbency; however, 2 cows fed the CON diet were borderline hypocalcemic based on blood measurement with the on-farm electrolyte analyzer and other visual signs, and were treated with intravenous $\mathrm{Ca}$ as a preventative measure. Two cows fed EXP exhibited signs of hypocalcemia (cold and lethargic) but did not warrant Ca treatment because the serum mineral results from the on-farm electrolyte 


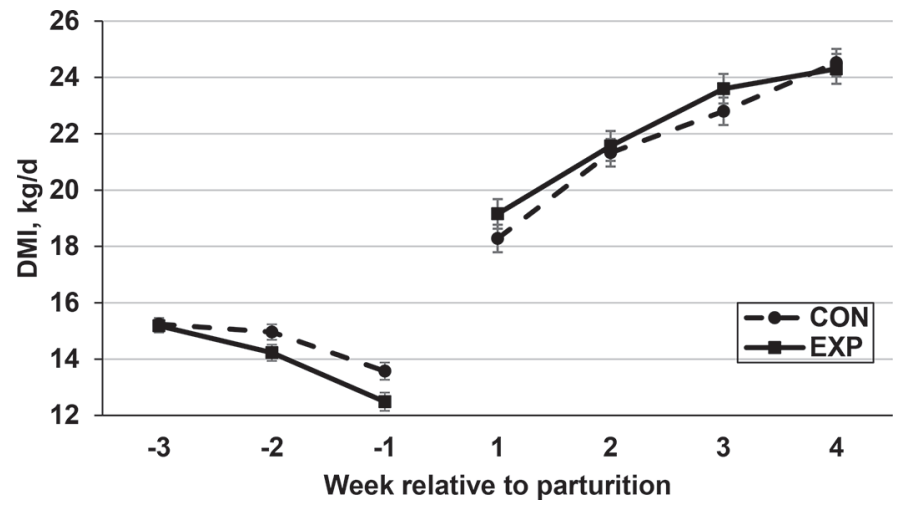

Figure 3. Least squares means and SE for prepartum and postpartum DMI $(\mathrm{kg} / \mathrm{d})$ for multiparous cows fed a control prepartum diet $(\mathrm{CON})$ or a control prepartum diet with the addition of synthetic zeolite A (EXP). Prepartum and postpartum data were analyzed separately. A treatment effect was detected during the prepartum period $(P=0.07)$ but not during the postpartum period $(P=0.51)$. A treatment by week effect was detected during the prepartum period $(P=$ $0.04)$ but not during the postpartum period $(P=0.16)$.

analyzer showed adequate Ca levels but low levels of $\mathrm{P}$ and $\mathrm{Mg}$; therefore, those 2 cows were treated with $\mathrm{P}$ and $\mathrm{Mg}$ as a preventative measure. Before electrolyte treatment, an additional serum sample was acquired for analysis at the Cornell Animal Health and Diagnostic
Center to confirm treatment decisions, and the mineral results are presented in Table 8.

Eleven out of 52 animals $(\mathrm{CON}=8$ cows, EXP $=$ 3 cows) were right-censored because they were culled before becoming pregnant $(\mathrm{n}=1)$ or did not become pregnant during the first 150 DIM $(\mathrm{n}=10)$. The median time to pregnancy in the first 150 DIM for animals fed EXP was $70 \mathrm{~d}$, whereas for cows fed CON it was 89 d (Figure 4A). When we controlled for parity, cows fed EXP tended to have a higher hazard of becoming pregnant within 150 DIM compared with cows fed CON [hazard ratio $(95 \% \mathrm{CI})=1.76(0.93-3.33) ; P=0.08$ ] Third-lactation and greater animals had a lower hazard of becoming pregnant within 150 DIM compared with second-lactation animals [0.54 (0.29-1.02); $P=0.06]$.

When observing the effects of hypocalcemia status on time to pregnancy, $0 / 12$ eucalcemic cows, $5 / 30 \mathrm{SCH}$ cows, and $6 / 10 \mathrm{cSCH}$ cows were right-censored. The median time to pregnancy in the first 150 DIM for eucalcemic cows was $69 \mathrm{~d}$ compared with $73 \mathrm{~d}$ for $\mathrm{SCH}$ cows. Only $40 \%$ of cows with cSCH became pregnant by 150 DIM (Figure 4B). Hypocalcemia status was found to be associated with time to pregnancy $(P=0.01)$. When we controlled for parity, cSCH cows had a lower hazard [0.18 (0.06-0.57); $P<0.01]$ of becoming pregnant within 150 DIM compared with eucalcemic cows;

Table 5. Least squares means and SE for prepartum and postpartum DMI, DMI as a percentage of BW, energy balance (EBAL), rumination, BW, change in BW, and BCS

\begin{tabular}{|c|c|c|c|c|c|c|}
\hline \multirow[b]{2}{*}{ Variable } & \multicolumn{2}{|c|}{ Treatment $^{1}$} & \multirow[b]{2}{*}{ SEM } & \multicolumn{3}{|c|}{$P$-value ${ }^{2}$} \\
\hline & $\mathrm{CON}$ & EXP & & $\mathrm{T}$ & $\mathrm{T} \times \mathrm{W}$ & $\mathrm{T} \times$ Parity $^{3}$ \\
\hline \multicolumn{7}{|l|}{ Prepartum $^{4}$} \\
\hline DMI, kg/d & 14.6 & 14.0 & 0.2 & 0.07 & 0.04 & 0.24 \\
\hline DMI, $\%$ of BW & 1.82 & 1.79 & 0.03 & 0.44 & 0.10 & 0.32 \\
\hline EBAL, Mcal/d & 5.4 & 4.4 & 0.4 & 0.05 & 0.11 & 0.26 \\
\hline Rumination, $\min / \mathrm{d}$ & 521 & 500 & 7 & 0.03 & 0.77 & 0.64 \\
\hline $\mathrm{BW}, \mathrm{kg}$ & 808 & 790 & 4 & $<0.001$ & 0.02 & 0.68 \\
\hline BW change. ${ }^{5} \mathrm{~kg}$ & 17 & 6 & 4 & 0.04 & - & 0.24 \\
\hline BCS & 3.37 & 3.29 & 0.02 & 0.008 & 0.32 & 0.53 \\
\hline \multicolumn{7}{|l|}{ Postpartum $^{6}$} \\
\hline DMI, kg/d & 21.7 & 22.2 & 0.5 & 0.51 & 0.16 & 0.51 \\
\hline DMI, $\%$ of BW & 3.09 & 3.16 & 0.06 & 0.36 & 0.20 & 0.64 \\
\hline $\mathrm{EBAL}, \mathrm{Mcal} / \mathrm{d}$ & -11.8 & -11.9 & 0.7 & 0.91 & 0.66 & 0.91 \\
\hline Rumination, $\min / \mathrm{d}$ & 512 & 523 & 12 & 0.61 & 0.34 & 0.07 \\
\hline $\mathrm{BW}, \mathrm{kg}$ & 713 & 708 & 5 & 0.42 & 0.82 & 0.85 \\
\hline BW change, ${ }^{7} \mathrm{~kg}$ & -36 & -36 & 8 & 0.96 & - & 0.29 \\
\hline BCS & 3.14 & 3.11 & 0.03 & 0.34 & 0.01 & 0.51 \\
\hline
\end{tabular}

${ }^{1} \mathrm{CON}=$ control diet; $\mathrm{EXP}=$ control diet plus synthetic zeolite $\mathrm{A}$.

${ }^{2} \mathrm{~T}=$ treatment; $\mathrm{W}=$ week.

${ }^{3}$ Parity $=$ cows entering second lactation versus third lactation and greater.

${ }^{4}$ Data collected weekly or daily and reduced to weekly means (DMI, rumination) in the $21 \mathrm{~d}$ before parturition. ${ }^{5}$ Difference between BW measurements at wk -3 and -1 relative to parturition.

${ }^{6}$ Data collected weekly or daily and reduced to weekly means (DMI, rumination) from parturition through 4 wk postpartum.

${ }^{7}$ Difference between BW measurements at wk 1 and 4 relative to parturition. 
Table 6. Least squares means for postpartum colostrum measurements, milk yield, and composition during the first 4 wk of lactation, and milk yield over the first 9 wk of lactation

\begin{tabular}{|c|c|c|c|c|c|c|}
\hline \multirow[b]{2}{*}{ Variable $^{1}$} & \multicolumn{2}{|c|}{ Treatment $^{2}$} & \multirow[b]{2}{*}{ SEM } & \multicolumn{3}{|c|}{$P$-value ${ }^{3}$} \\
\hline & $\mathrm{CON}$ & EXP & & $\mathrm{T}$ & $\mathrm{T} \times \mathrm{W}$ & $\mathrm{T} \times$ Parity $^{4}$ \\
\hline Colostrum weight, $\mathrm{kg}$ & 7.3 & 5.8 & 0.8 & 0.16 & - & 0.13 \\
\hline Colostrum volume, $\mathrm{L}$ & 7.3 & 5.7 & 0.8 & 0.13 & - & 0.12 \\
\hline Colostrum IgG, mg/dL & 7,628 & 8,342 & 483 & 0.29 & - & 0.95 \\
\hline Colostrum IgG yield, $\mathrm{g}$ & 494 & 441 & 41 & 0.35 & - & 0.10 \\
\hline Colostrum, \% Brix & 25.9 & 27.2 & 0.7 & 0.19 & - & 0.25 \\
\hline \multicolumn{7}{|l|}{ Milk yield, $\mathrm{kg} / \mathrm{d}$} \\
\hline wk 1-4 & 48.0 & 47.5 & 0.8 & 0.58 & 0.99 & 0.02 \\
\hline wk 1-9 & 51.7 & 50.7 & 0.8 & 0.37 & 0.84 & 0.05 \\
\hline Fat, \% & 4.17 & 4.32 & 0.08 & 0.17 & 0.05 & 0.58 \\
\hline Fat, $\mathrm{kg} / \mathrm{d}$ & 1.98 & 2.03 & 0.04 & 0.35 & 0.26 & 0.21 \\
\hline $3.5 \% \mathrm{FCM}^{5}{ }^{5} \mathrm{~kg} / \mathrm{d}$ & 52.9 & 53.6 & 1.0 & 0.59 & 0.45 & 0.11 \\
\hline True protein, \% & 3.19 & 3.30 & 0.05 & 0.09 & 0.24 & 0.10 \\
\hline True protein, $\mathrm{kg} / \mathrm{d}$ & 1.51 & 1.55 & 0.03 & 0.33 & 0.88 & 0.49 \\
\hline Lactose, \% & 4.58 & 4.59 & 0.02 & 0.78 & 0.59 & 0.22 \\
\hline Lactose, $\mathrm{kg} / \mathrm{d}$ & 2.22 & 2.20 & 0.04 & 0.67 & 0.54 & 0.08 \\
\hline TS, \% & 13.03 & 13.32 & 0.11 & 0.07 & 0.18 & 0.19 \\
\hline $\mathrm{TS}, \mathrm{kg} / \mathrm{d}$ & 6.23 & 6.30 & 0.11 & 0.65 & 0.66 & 0.13 \\
\hline $\mathrm{ECM},{ }^{6} \mathrm{~kg} / \mathrm{d}$ & 53.0 & 53.8 & 0.9 & 0.50 & 0.57 & 0.14 \\
\hline ECM/DMI & 2.47 & 2.47 & 0.05 & 0.95 & 0.47 & 0.73 \\
\hline MUN, mg/dL & 12.46 & 10.90 & 0.44 & 0.01 & 0.87 & 0.47 \\
\hline SCS & 1.07 & 1.08 & 0.26 & 0.98 & 0.72 & 0.91 \\
\hline \multicolumn{7}{|l|}{ De novo fatty acids } \\
\hline $\mathrm{g} / 100 \mathrm{~g}$ of milk & 0.83 & 0.87 & 0.02 & 0.21 & 0.71 & 0.32 \\
\hline $\mathrm{g} / 100 \mathrm{~g}$ of fatty acids & 21.5 & 21.5 & 0.4 & 0.95 & 0.14 & 0.35 \\
\hline $\mathrm{g} / \mathrm{d}$ & 395 & 408 & 11 & 0.39 & 0.30 & 0.58 \\
\hline \multicolumn{7}{|l|}{ Mixed fatty acids } \\
\hline $\mathrm{g} / 100 \mathrm{~g}$ of milk & 1.32 & 1.42 & 0.04 & 0.05 & 0.96 & 0.07 \\
\hline $\mathrm{g} / 100 \mathrm{~g}$ of fatty acids & 33.7 & 35.0 & 0.7 & 0.18 & 0.45 & 0.01 \\
\hline $\mathrm{g} / \mathrm{d}$ & 621 & 668 & 19 & 0.08 & 0.58 & 0.81 \\
\hline \multicolumn{7}{|l|}{ Preformed fatty acids } \\
\hline $\mathrm{g} / 100 \mathrm{~g}$ of milk & 1.74 & 1.77 & 0.05 & 0.73 & $<0.01$ & 0.50 \\
\hline $\mathrm{g} / 100 \mathrm{~g}$ of fatty acids & 44.9 & 43.5 & 0.9 & 0.53 & 0.04 & 0.04 \\
\hline $\mathrm{g} / \mathrm{d}$ & 834 & 830 & 24 & 0.96 & 0.02 & 0.19 \\
\hline
\end{tabular}

${ }^{1}$ Data collected weekly or daily and reduced to weekly means (milk yield) from parturition through 4 wk postpartum or through 9 wk postpartum (milk yield).

${ }^{2} \mathrm{CON}=$ control diet; $\mathrm{EXP}=$ control diet plus synthetic zeolite $\mathrm{A}$.

${ }^{3} \mathrm{~T}=$ treatment; $\mathrm{W}=$ week.

${ }^{4}$ Parity $=$ second lactation versus third lactation and greater.

${ }^{5} 3.5 \% \mathrm{FCM}=(0.432 \times \mathrm{kg}$ of weekly average milk yield $)+(16.216 \times \mathrm{kg}$ of fat $)$.

${ }^{6} \mathrm{ECM}=(0.327 \times \mathrm{kg}$ of weekly average milk yield $)+(12.95 \times \mathrm{kg}$ of fat $)+(7.65 \times \mathrm{kg}$ of true protein $)$.

Table 7. Incidence of health disorders and electrolyte treatment through 28 DIM for multiparous cows fed a control prepartum diet $(\mathrm{CON})$ or a control prepartum diet with the addition of synthetic zeolite A (EXP)

\begin{tabular}{lccc}
\hline & \multicolumn{2}{c}{ Treatment } & \\
\cline { 2 - 3 } Disorder & CON & EXP & $P$-value \\
\hline Clinical mastitis & 3 & 0 & 0.09 \\
Metritis & 0 & 0 & - \\
Retained placenta & 5 & 3 & 0.55 \\
Displaced abomasum & 0 & 3 & 0.06 \\
Milk fever & 0 & 0 & - \\
Injury & 3 & 3 & 0.55 \\
Hyperketonemia & 10 & 8 & 0.77 \\
Pneumonia & 1 & 3 & 0.25 \\
Ca treatment & 2 & 0 & 0.17 \\
P and Mg treatment & 0 & 2 & 0.13 \\
\hline
\end{tabular}

however, SCH cows did not differ from eucalcemic cows $(P=0.29)$. Third-lactation and greater animals tended to have a lower hazard $[0.59(0.31-1.11) ; P=0.10)$ than second-lactation animals.

\section{DISCUSSION}

The main objective of this study was to determine the effect of feeding synthetic zeolite A for 3 wk before expected calving on serum macromineral status and subclinical hypocalcemia. Previous studies showed similar results in serum Ca status during the periparturient period for cows fed synthetic zeolite A (Thilsing-Hansen et al., 2002; Pallesen et al., 2008; Grabherr et al., 2009a). On average, cows fed synthetic zeolite A had Ca 
Table 8. Serum mineral concentrations before electrolyte treatment, as analyzed at the Cornell University Animal Health Diagnostic Center (Ithaca, NY), of cows classified as borderline hypocalcemic by the herd health crew

\begin{tabular}{llccccc}
\hline Cow ID & Treatment $^{1}$ & DIM & Ca, mmol/L & P, mmol/L & $\mathrm{Mg}, \mathrm{mmol} / \mathrm{L}$ & Electrolyte treatment \\
\hline 448 & CON & 6 & 1.77 & 1.68 & 0.91 & $\mathrm{Ca}$ \\
9599 & EXP & 0 & 1.97 & 0.61 & 0.62 & $\mathrm{P}, \mathrm{Mg}$ \\
9747 & EXP & 2 & 2.20 & 0.90 & 0.70 & $\mathrm{P}, \mathrm{Mg}$ \\
9979 & CON & 0 & 1.37 & 1.39 & 0.91 & $\mathrm{Ca}$ \\
\hline
\end{tabular}

${ }^{1} \mathrm{CON}=$ control diet; $\mathrm{EXP}=$ control diet plus synthetic zeolite A.

concentrations approximately $0.4 \mathrm{mmol} / \mathrm{L}$ greater than those of the control group during the first DIM. Similar differences were found within the first DIM when utilizing a low-Ca prepartum diet approach compared with a high-Ca prepartum diet (Green et al., 1981). Differences in serum Ca concentrations were reflected in the proportion of cows per treatment with $\mathrm{SCH}$ within the first 3 DIM. None of the EXP-fed cows were categorized retrospectively as having $\mathrm{cSCH}$, whereas $34 \%$ of the cows fed the CON diet were classified as having cSCH. Caixeta et al. (2017) observed decreased ovarian function and decreased odds of becoming pregnant at first service for cows diagnosed with $\mathrm{cSCH}$ compared with eucalcemic or SCH cows.

Cows fed EXP had a pronounced decrease in serum $\mathrm{P}$ during the prepartum and immediate postpartum period compared with the cows fed CON. Previous studies have shown similar results when cows were fed diets supplemented with zeolite A (Thilsing-Hansen et al., 2002; Pallesen et al., 2008; Grabherr et al., 2009a). The decrease in serum $\mathrm{P}$ is likely due to the decreased availability of dietary $\mathrm{P}$ when supplemented with zeolite A (Thilsing et al., 2007). Although the treatment diets supplied about the same amount of $\mathrm{P}$, Thilsing et al. (2006) reported that zeolite A will bind to dietary P at a $\mathrm{pH}$ close to that of the abomasum and small intestine environment, rendering dietary $\mathrm{P}$ unavailable for absorption. Elevated blood P can inhibit the conversion of 1,25-dihydroxyvitamin D from 25-hydroxyvitamin D when blood $\mathrm{P}$ is around or greater than $2.0 \mathrm{mmol} / \mathrm{L}$ (Goff, 2006). Without this conversion, Ca absorption activity is not increased in the small intestine, regardless of PTH synthesis activation (Goff, 2006). Similarly, Kichura et al. (1982) showed that feeding a diet low in $\mathrm{P}$ and $\mathrm{Ca}$ during the prepartum period improved $\mathrm{Ca}$ status compared with feeding a diet high in $\mathrm{P}$ and low in Ca. More recently, Cohrs et al. (2018) observed improved Ca status at d 1 and 2 of lactation for cows fed a prepartum diet low in $\mathrm{P}$ compared with cows fed adequate P. A previous synthetic zeolite A study observed an increase in serum 1,25-dihydroxyvitamin $\mathrm{D}$, suggesting the increased absorptive capacity of $\mathrm{Ca}$
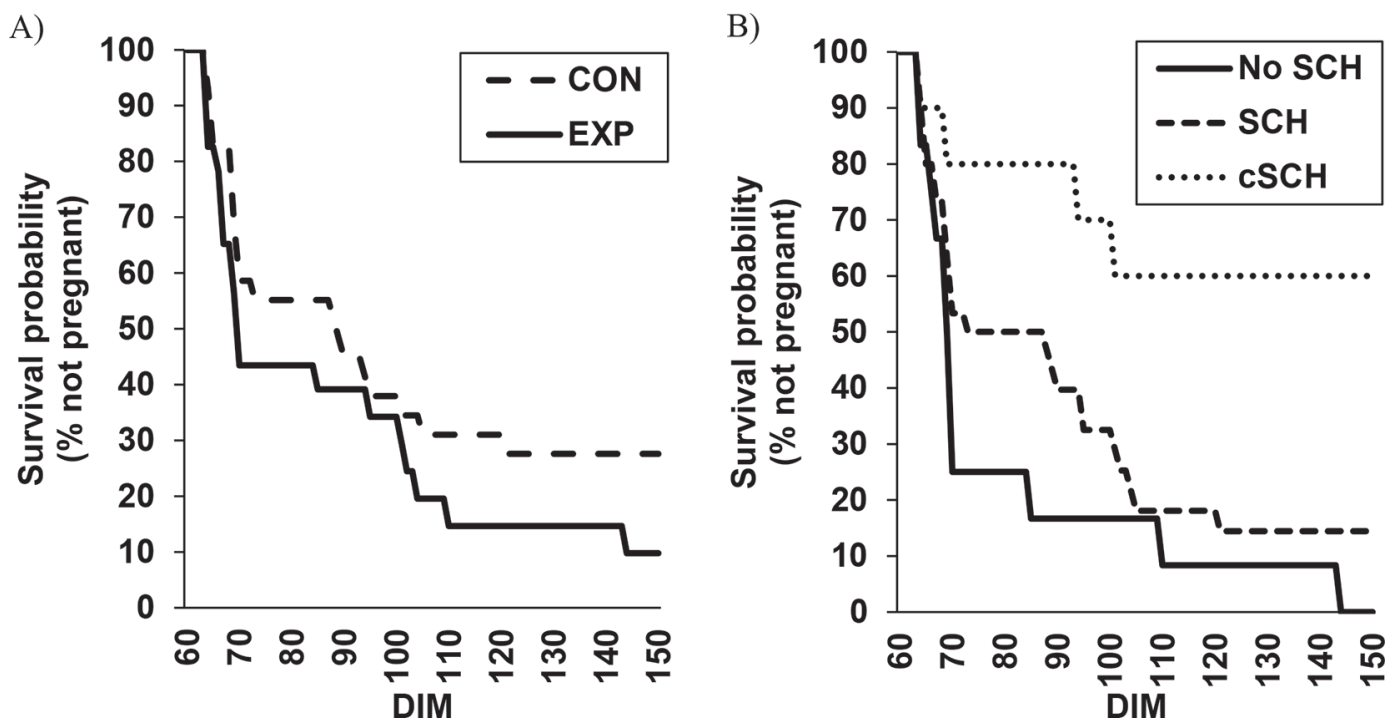

Figure 4. Survival curves estimating the time to pregnancy for multiparous cows (A) fed a control prepartum diet (CON) or a control prepartum diet with the addition of synthetic zeolite A (EXP), and (B) categorized as being eucalcemic (no SCH; 0 samples with Ca $<2.125$ $\mathrm{mmol} / \mathrm{L}$ ), subclinical hypocalcemic (SCH; 1 to 3 samples with $\mathrm{Ca}<2.125 \mathrm{mmol} / \mathrm{L}$ ), or chronic subclinical hypocalcemic (cSCH; 4 samples with $\mathrm{Ca}<2.125 \mathrm{mmol} / \mathrm{L}$ ) between parturition and 3 DIM. 
in the intestines (Thilsing-Hansen et al., 2002). The decrease in prepartum serum $\mathrm{P}$ in cows fed zeolite $\mathrm{A}$ could be a plausible mechanism for the improved Ca status exhibited; however, future work is needed to evaluate this hypothesis (Pallesen et al., 2008). It is unclear how hypophosphatemia independently affects cows because it generally occurs concurrently with hypocalcemia. Unlike the situation with $\mathrm{Ca}$, we are not aware of published epidemiological studies that relate circulating concentrations of $\mathrm{P}$ during the periparturient period with health, production, and reproduction outcomes, suggesting that there is an opportunity for more research in this area.

Treatment differences were detected in serum $\mathrm{Mg}$ during the week before calving and within the first DIM; however, concentrations were still within the normal range of 0.75 to $1.0 \mathrm{mmol} / \mathrm{L}$ (Goff, 1999). Regulatory mechanisms do not exist for maintaining blood $\mathrm{Mg}$ concentration; rather, it is a reflection of the absorption of $\mathrm{Mg}$ from the diet (Goff, 2006). Although Thilsing et al. (2006) showed Mg-binding capabilities by zeolite A, mean serum $\mathrm{Mg}$ concentrations remained within the normal range, indicating that dietary $\mathrm{Mg}$ supplementation was likely adequate for both treatments. It has been proposed by others that the transient increase in serum $\mathrm{Mg}$ concentration at parturition (as seen in the cows fed $\mathrm{CON}$ ) is due to increased reabsorption in the renal tubules of the kidney in response to increased circulating PTH as a result of hypocalcemia (Riond et al., 1995; Goff, 2006), which then decreases through 3 DIM due to the increased requirement for colostrum (Shappell et al., 1987). It is unclear why we did not see a similar pattern in the cows fed EXP.

Our secondary objective was to determine the effect of feeding synthetic zeolite A for the 3 wk before expected calving on DMI, milk yield, and other aspects of performance. Previous studies observed decreased DMI when feeding zeolite A for 2 wk before expected calving (Thilsing et al., 2007; Pallesen et al., 2008; Grabherr et al., 2009a). In the current study, we observed a treatment by week effect such that EXP cows did not differ in DMI at 3 wk before calving but had a greater reduction in DMI than CON-fed cows as parturition approached. Although absolute DMI tended to be decreased in cows fed EXP compared with CON, we detected no treatment effect when comparing DMI as a percentage of BW, which was likely due to the EXP-fed cows not gaining as much BW during the prepartum period due to a lower DMI compared with CON-fed cows. There were no treatment effects on DMI during the postpartum period.

Thilsing et al. (2006) stated that there are unknown effects of having low available $\mathrm{Ca}$ in the rumen due to zeolite A supplementation; however, we speculate that zeolite A supplementation affects the rate of digestion by altering the availability of $\mathrm{Ca}$ and potentially other macrominerals. Cows fed the EXP diet had decreased rumination during the prepartum period compared with cows fed the CON diet. Compared with other studies that measured rumination during the dry cow period, both treatments had above-average daily rumination rates (Liboreiro et al., 2015; Kaufman et al., 2016; Paudyal et al., 2016) suggesting that the observed reduction may not be of critical importance. The difference in time spent ruminating during the prepartum period between the 2 treatments may reflect the difference in particle size (Beauchemin, 2018) or DMI. Although particle size was not determined in this study, the diets were identical except for the addition of zeolite A to the EXP diet, creating a dilution effect of the diet. Therefore, a greater proportion of the EXP diet had a smaller particle size due to the zeolite A compared with the CON diet. In sheep, PTH has been shown to have relaxing effects on the reticulo-rumen smooth muscle, resulting in decreased ruminal contractions (Care et al., 1999). Although we did not measure blood PTH concentrations in the current study, it is plausible that the EXP-fed cows had increased circulating PTH compared with the CON-fed cows, resulting in slight differences in rumination rates. However, there are discrepancies in the literature as to whether PTH is activated. One previous zeolite A study did not show an increase in circulating PTH (Enemark et al., 2003) while ThilsingHansen et al. (2002) observed an increase in serum 1,25-dihydroxyvitamin D, indicating PTH activation; however, indicators of bone resorption were not observed in this study. Future work should investigate the role of PTH on rumination activity in zeolite A-fed cows. Postpartum rumination did not differ between treatments; however, there were numerical differences during the first week of lactation such that cows fed the EXP diet were ruminating for an additional 30 min/d compared with the CON-fed cows while consuming approximately $1 \mathrm{~kg} / \mathrm{d}$ more DM. This may be a reflection of the improved Ca status during the first week of lactation in the EXP-fed cows as rumination requires smooth muscle to contract and is dependent on the ionized $\mathrm{Ca}$ concentration in the extracellular fluid (Hall, 2011).

To our knowledge, previous studies did not investigate colostrum quantity or quality measures as affected by dietary zeolite A. Shappell et al. (1987) showed an increase in colostrum $\mathrm{Ca}$ concentration when a low $\mathrm{Ca}$ diet was fed during the prepartum period, indicating that $\mathrm{Ca}$ status is linked to colostrum composition. Adequate blood $\mathrm{Ca}$ concentration has been linked to improved immune function during the transition period (Kimura et al., 2006; Martinez et al., 2012) and Ca has 
been recognized as being an important signaling molecule in B cell function that could influence IgG production (Baba and Kurosaki, 2011). Despite improved Ca status during the periparturient period in cows fed the EXP diet, these cows did not have significantly improved IgG concentration or yield compared with cows fed CON.

We found no differences in milk yield between treatments, similar to results from previous studies (Thilsing-Hansen et al., 2002; Thilsing et al., 2007; Grabherr et al., 2009a), nor did we observe a difference in ECM. Fat and protein yield also did not differ between treatments as seen in previous studies (Thilsing-Hansen et al., 2002; Thilsing et al., 2007), whereas Grabherr et al. (2009a) reported no differences in fat, protein, and lactose concentrations. The treatment by week effect seen with the milk fat concentration is likely a reflection of either body fat mobilization or absorption from the diet, because we saw similar trends with the preformed FA yield and concentration. Future studies should look at longer term milk production effects with larger numbers of cows.

Numerous trace minerals are incorporated into antioxidant enzymes and play a role in the immune system, aiding the immune function of the cow during the transition period (Spears and Weiss, 2008). To our knowledge, previous studies on synthetic zeolite A have not investigated whether the compound has the capacity to bind to dietary trace minerals. Although we did not specifically look at the binding capacity of zeolite A, we did not see any significant differences in oxidant status between treatments, indicating that zeolite A supplementation did not negatively affect the antioxidant defense system.

To our knowledge, previous synthetic zeolite A studies have not evaluated reproductive performance. Cow numbers were limited in this study and caution should be used when interpreting these results. Feeding the EXP diet tended to result in an improved time to pregnancy, which is likely related to Ca status of the cow as observed by Martinez et al. (2012) and Caixeta et al. (2017). Martinez et al. (2012) observed a tendency for eucalcemic cows to have a greater hazard of becoming pregnant within 230 DIM compared with SCH cows [1.61 (0.97-2.65); $P=0.06]$, whereas Caixeta et al. (2017) did not find a difference between hypocalcemia groups and time to pregnancy; however, they only evaluated time to pregnancy within 120 DIM and used a total blood Ca concentration of $\leq 2.15 \mathrm{mmol} / \mathrm{L}$. Compared with eucalcemic cows, $\mathrm{cSCH}$ cows did have lower odds of becoming pregnant at first service. Further research involving more cows is needed to validate the improved time to pregnancy findings of this study.

\section{CONCLUSIONS}

Supplementing diets with synthetic zeolite A for $3 \mathrm{wk}$ before parturition improved Ca status in cows during the periparturient period yet resulted in similar postpartum performance outcomes between the 2 treatment groups. Feeding zeolite A decreased SCH compared with the control group and eliminated $\mathrm{cSCH}$. Cows fed the zeolite A had improved time to pregnancy, although future work should further evaluate effects of prepartum zeolite A supplementation on postpartum reproductive performance. We also did not observe a treatment effect on oxidative metabolism, as reflected in the lack of change of AOP, RONS, and OSi. Feeding synthetic zeolite A during the prepartum period is effective in improving $\mathrm{Ca}$ status during the postpartum period.

\section{ACKNOWLEDGMENTS}

The authors acknowledge and thank Protekta Inc. (Lucknow, ON, Canada) and Vilofoss (Graasten, Denmark) for partial financial support of this project; Lisa Furman and the staff at the Cornell University Ruminant Center for the care of the animals; Helen Korzec, Sarah LaCount, and undergraduate research assistants Claira Seely, Shana Coffey, Reilly Pierce, Brooke Ryan, Courtney Dearnley, and Conor McCabe (all at Cornell University) for their invaluable assistance with the execution of this research. The authors also thank Ángel Abuelo (at the School of Animal and Veterinary Sciences at Charles Sturt University, New South Wales, Australia, at the time of communication) for his insight on oxidant status.

\section{REFERENCES}

Abuelo, A., J. C. Gandy, L. Neuder, J. Brester, and L. M. Sordillo. 2016. Short communication: Markers of oxidant status and inflammation relative to the development of claw lesions associated with lameness in early lactation cows. J. Dairy Sci. 99:5640-5648. https: //doi.org/10.3168/jds.2015-10707.

Abuelo, A., J. Hernández, J. L. Benedito, and C. Castillo. 2013. Oxidative stress index (OSi) as a new tool to assess redox status in dairy cattle during the transition period. Animal 7:1374-1378. https://doi.org/10.1017/S1751731113000396.

Abuelo, A., J. Hernández, J. L. Benedito, and C. Castillo. 2015. The importance of the oxidative status of dairy cattle in the periparturient period: Revisiting antioxidant supplementation. J. Anim. Physiol. Anim. Nutr. (Berl.) 99:1003-1016. https://doi.org/10 .1111/jpn.12273.

AOAC International. 2000. Official Methods of Analysis. 17th ed. AOAC International, Arlington, VA.

Baba, Y., and T. Kurosaki. 2011. Impact of $\mathrm{Ca}^{2+}$ signaling on B cell function. Trends Immunol. 32:589-594. https://doi.org/10.1016/j it.2011.09.004.

Beauchemin, K. A. 2018. Invited review: Current perspectives on eating and rumination activity in dairy cows. J. Dairy Sci. 101:47624784. https://doi.org/10.3168/jds.2017-13706. 
Caixeta, L. S., P. A. Ospina, M. B. Capel, and D. V. Nydam. 2017. Association between subclinical hypocalcemia in the first 3 days of lactation and reproductive performance of dairy cows. Theriogenology 94:1-7. https://doi.org/10.1016/j.theriogenology.2017.01 .039 .

Care, A. D., S. K. Abbas, J. Harmeyer, and R. Boivin. 1999. The relaxant effects of parathyroid hormone(1-34) and parathyroid hormone-related protein(1-34) on ovine reticulo-ruminal smooth muscle in vivo. Exp. Physiol. 84:665-675. https://doi.org/10.1111/ j.1469-445X.1999.01814.x.

Celi, P. 2011. Biomarkers of oxidative stress in ruminant medicine. Immunopharmacol. Immunotoxicol. 33:233-240. https://doi.org/ 10.3109/08923973.2010.514917.

Chapinal, N., M. Carson, T. F. Duffield, M. Capel, S. Godden, M. Overton, J. E. P. Santos, and S. J. LeBlanc. 2011. The association of serum metabolites with clinical disease during the transition period. J. Dairy Sci. 94:4897-4903. https://doi.org/10.3168/jds $.2010-4075$.

Chapinal, N., M. E. Carson, S. J. LeBlanc, K. E. Leslie, S. Godden, M. Capel, J. E. P. Santos, M. W. Overton, and T. F. Duffield. 2012. The association of serum metabolites in the transition period with milk production and early-lactation reproductive performance. J. Dairy Sci. 95:1301-1309. https://doi.org/10.3168/jds.2011-4724.

Cohrs, I., M. R. Wilkens, and W. Grünberg. 2018. Short communication: Effect of dietary phosphorus deprivation in late gestation and early lactation on the calcium homeostasis of periparturient dairy cows. J. Dairy Sci. 101:9591-9598. https://doi.org/10.3168/ jds.2018-14642.

Edmonson, A. J., I. J. Lean, L. D. Weaver, T. Farver, and G. Webster. 1989. A body condition scoring chart for Holstein dairy cows. J. Dairy Sci. 72:68-78. https://doi.org/10.3168/jds.S0022 -0302(89)79081-0.

Enemark, J. M., A. Frandsen, T. Thilsing-Hansen, and R. Jørgensen. 2003. Aspects of physiological effects of sodium zeolite A supplementation in dry, non-pregnant dairy cows fed grass silage. Acta Vet. Scand. Suppl. 97:97-117.

Fitts, J. E., and D. Laird. 2004. Chapter 10: Direct microscopic method for bacteria or somatic cells. Pages 269-280 in Standard Methods for Examination of Dairy Products. H. M. Wehr and J. F. Frank, ed. American Public Health Association, Washington, DC

Gaines, W. L., and F. A. Davidson. 1923. Relation between percentage fat content and yield of milk: correction of milk yield for fat content. Illinois Agric. Exp. Sta. Bull. No. 245. University of Illinois, Urbana, Champaign, IL

Goff, J. P. 1999. Treatment of calcium, phosphorus, and magnesium balance disorders. Vet. Clin. North Am. Food Anim. Pract. 15:619-639. https://doi.org/10.1016/S0749-0720(15)30167-5.

Goff, J. P. 2006. Macromineral physiology and application to the feeding of the dairy cow for prevention of milk fever and other periparturient mineral disorders. Anim. Feed Sci. Technol. 126:237-257. https://doi.org/10.1016/j.anifeedsci.2005.08.005.

Goff, J. P. 2008. The monitoring, prevention, and treatment of milk fever and subclinical hypocalcemia in dairy cows. Vet. J. 176:50-57. https://doi.org/10.1016/j.tvjl.2007.12.020.

Goff, J. P., and R. L. Horst. 1997. Physiological changes at parturition and their relationship to metabolic disorders. J. Dairy Sci. 80:1260-1268. https://doi.org/10.3168/jds.S0022-0302(97)76055 $-7$.

Goings, R. L., N. L. Jacobson, D. C. Beitz, E. T. Littledike, and K. D. Wiggers. 1974. Prevention of parturient paresis by a prepartum, calcium-deficient diet. J. Dairy Sci. 57:1184-1188. https://doi.org/ 10.3168/jds.S0022-0302(74)85034-4.

Grabherr, H., M. Spolders, M. Fürll, and G. Flachowsky. 2009a. Effect of several doses of zeolite A on feed intake, energy metabolism and on mineral metabolism in dairy cows around calving. J. Anim. Physiol. Anim. Nutr. (Berl.) 93:221-236. https://doi.org/10.1111/ j.1439-0396.2008.00808.x.

Grabherr, H., M. Spolders, P. Lebzien, L. Hüther, G. Flachowsky, M. Fürll, and M. Grün. 2009b. Effect of zeolite A on rumen fermentation and phosphorus metabolism in dairy cows. Arch. Anim. Nutr. 63:321-336. https://doi.org/10.1080/17450390903020430.
Green, H. B., R. L. Horst, D. C. Beitz, and E. T. Littledike. 1981 Vitamin D metabolites in plasma of cows fed a prepartum low-calcium diet for prevention of parturient hypocalcemia. J. Dairy Sci 64:217-226. https://doi.org/10.3168/jds.S0022-0302(81)82557-X.

Hall, J. E. 2011. Guyton and Hall Textbook of Medical Physiology. 12th ed. Elsevier, Philadelphia, PA.

Horst, R. L., J. P. Goff, and T. A. Reinhardt. 2005. Adapting to the transition between gestation and lactation: Differences between rat, human and dairy cow. J. Mammary Gland Biol. Neoplasia 10:141-156. https://doi.org/10.1007/s10911-005-5397-x.

House, W. A., and A. W. Bell. 1993. Mineral accretion in the fetus and adnexa during late gestation in Holstein cows. J. Dairy Sci. 76:2999-3010. https://doi.org/10.3168/jds.S0022-0302(93)77639 -0 .

Kaufman, E. I., S. J. LeBlanc, B. W. McBride, T. F. Duffield, and T. J. DeVries. 2016. Association of rumination time with subclinical ketosis in transition dairy cows. J. Dairy Sci. 99:5604-5618. https: //doi.org/10.3168/jds.2015-10509.

Kaylegian, K. E., G. E. Houghton, J. M. Lynch, J. R. Fleming, and D. M. Barbano. 2006. Calibration of infrared milk analyzers: modified milk versus producer milk. J. Dairy Sci. 89:2817-2832.

Kaylegian, K. E., J. M. Lynch, J. R. Fleming, and D. M. Barbano. 2009. Influence of fatty acid chain length and unsaturation on midinfrared milk analysis. J. Dairy Sci. 92:2485-2501.

Kichura, T. S., R. L. Horst, D. C. Beitz, and E. T. Littledike. 1982 Relationships between prepartal dietary calcium and phosphorus, vitamin D metabolism, and parturient paresis in dairy cows. J. Nutr. 112:480-487.

Kimura, K., T. A. Reinhardt, and J. P. Goff. 2006. Parturition and hypocalcemia blunts calcium signals in immune cells of dairy cattle. J. Dairy Sci. 89:2588-2595. https://doi.org/10.3168/jds.S0022 $-0302(06) 72335-9$.

Leno, B. M., C. M. Ryan, T. Stokol, D. Kirk, K. P. Zanzalari, J. D. Chapman, and T. R. Overton. 2017. Effects of prepartum dietary cation-anion difference on aspects of peripartum mineral and energy metabolism and performance of multiparous Holstein cows. J. Dairy Sci. 100:4604-4622. https://doi.org/10.3168/jds.2016-12221.

Liboreiro, D. N., K. S. Machado, P. R. B. Silva, M. M. Maturana, T K. Nishimura, A. P. Brandão, M. I. Endres, and R. C. Chebel. 2015. Characterization of peripartum rumination and activity of cows diagnosed with metabolic and uterine diseases. J. Dairy Sci. 98:6812-6827. https://doi.org/10.3168/jds.2014-8947.

Martinez, N., C. A. Risco, F. S. Lima, R. S. Bisinotto, L. F. Greco, E. S. Ribeiro, F. Maunsell, K. Galvão, and J. E. P. Santos. 2012. Evaluation of peripartal calcium status, energetic profile, and neutrophil function in dairy cows at low or high risk of developing uterine disease. J. Dairy Sci. 95:7158-7172.

McArt, J. A. A., D. V. Nydam, and G. R. Oetzel. 2013. Dry period and parturient predictors of early lactation hyperketonemia in dairy cattle. J. Dairy Sci. 96:198-209. https://doi.org/10.3168/ jds.2012-5681.

NRC. 2001. Nutrient Requirements of Dairy Cattle. 7th rev. ed. Natl. Acad. Press, Washington, DC.

Pallesen, A., F. Pallesen, R. J. Jørgensen, and T. Thilsing. 2008. Effect of pre-calving zeolite, magnesium and phosphorus supplementation on periparturient serum mineral concentrations. Vet. J. 175:234-239. https://doi.org/10.1016/j.tvjl.2007.01.007.

Paudyal, S., F. Maunsell, J. Richeson, C. Risco, A. Donovan, and P Pinedo. 2016. Peripartal rumination dynamics and health status in cows calving in hot and cool seasons. J. Dairy Sci. 99:9057-9068. https://doi.org/10.3168/jds.2016-11203.

Re, R., N. Pellegrini, A. Proteggente, A. Pannala, M. Yang, and C. Rice-Evans. 1999. Antioxidant activity applying an improved ABTS radical cation decolorization assay. Free Radic. Biol. Med. 26:1231-1237. https://doi.org/10.1016/S0891-5849(98)00315-3.

Riond, J.-L., N. Kocabagli, U. E. Spichiger, and M. Wanner. 1995. The concentration of ionized magnesium in serum during the periparturient period of non-paretic dairy cows. Vet. Res. Commun. 19:195-203. https://doi.org/10.1007/BF01839298.

Shappell, N. W., J. H. Herbein, L. J. Deftos, and R. J. Aiello. 1987. Effects of dietary calcium and age on parathyroid hormone, calci- 
tonin and serum and milk minerals in the periparturient dairy cow. J. Nutr. 117:201-207.

Shook, G. E. 1993. Genetic improvement of mastitis through selection on somatic cell count. Vet. Clin. North Am. Food Anim. Pract. 9:563-581. https://doi.org/10.1016/S0749-0720(15)30622-8.

Spears, J. W., and W. P. Weiss. 2008. Role of antioxidants and trace elements in health and immunity of transition dairy cows. Vet. J. 176:70-76. https://doi.org/10.1016/j.tvjl.2007.12.015.

Thilsing, T., R. J. Jørgensen, and H. D. Poulsen. 2006. In vitro binding capacity of zeolite A to calcium, phosphorus and magnesium in rumen fluid as influenced by changes in $\mathrm{pH}$. J. Vet. Med. A Physiol. Pathol. Clin. Med. 53:57-64. https://doi.org/10.1111/j.1439-0442 .2006.00798.x.

Thilsing, T., T. Larsen, R. J. Jørgensen, and H. Houe. 2007. The effect of dietary calcium and phosphorus supplementation in zeolite A treated dry cows on periparturient calcium and phosphorus homeostasis. J. J. Vet. Med. A Physiol. Pathol. Clin. Med. 54:82-91. https://doi.org/10.1111/j.1439-0442.2007.00887.x.

Thilsing-Hansen, T., and R. J. Jørgensen. 2001. Hot topic: Prevention of parturient paresis and subclinical hypocalcemia in dairy cows by zeolite A administration in the dry period. J. Dairy Sci 84:691-693. https://doi.org/10.3168/jds.S0022-0302(01)74523-7.
Thilsing-Hansen, T., R. J. Jørgensen, J. M. D. Enemark, and T. Larsen. 2002. The effect of zeolite A supplementation in the dry period on periparturient calcium, phosphorus, and magnesium homeostasis. J. Dairy Sci. 85:1855-1862. https://doi.org/10.3168/jds.S0022 $-0302(02) 74259-8$

Tyrrell, H. F., and J. T. Reid. 1965. Prediction of the energy value of cow's milk. J. Dairy Sci. 48:1215-1223. https://doi.org/10.3168/ jds.S0022-0302(65)88430-2.

Wojciechowski, K. L., and D. M. Barbano. 2016. Prediction of fatty acid chain length and unsaturation of milk fat by mid-infrared milk analysis. J. Dairy Sci. 99:8561-8570.

Wojciechowski, K. L., C. Melilli, and D. M. Barbano. 2016. A proficiency test system to improve performance of milk analysis methods and produce reference values for component calibration samples for infrared milk analysis. J. Dairy Sci. 99:6808-6827.

Woolpert, M. E., H. M. Dann, K. W. Cotanch, C. Melilli, L. E. Chase, R. J. Grant, and D. M. Barbano. 2016. Management, nutrition, and lactation performance are related to bulk tank milk de novo fatty acid concentration on northeastern US dairy farms. J. Dairy Sci. 99:8486-8497. 